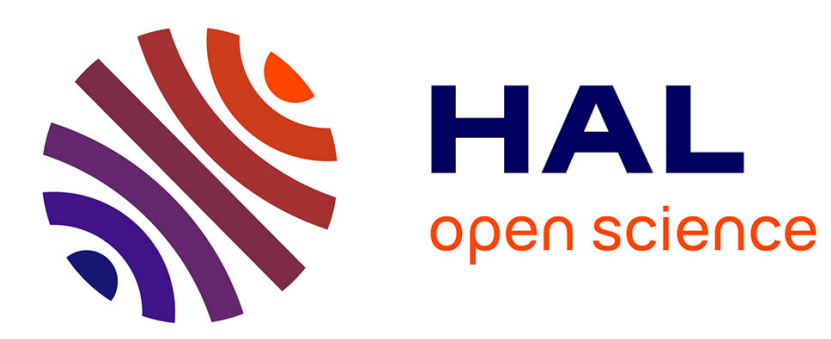

\title{
A comprehensive phylogeny of the gundis (Ctenodactylinae, Ctenodactylidae, Rodentia)
}

Raquel López-Antoñanzas, Fabien Knoll

\section{To cite this version:}

Raquel López-Antoñanzas, Fabien Knoll. A comprehensive phylogeny of the gundis (Ctenodactylinae, Ctenodactylidae, Rodentia). Journal of Systematic Palaeontology, 2011, 9 (3), pp.379 - 398. 10.1080/14772019.2010.529175 . hal-01920843

\section{HAL Id: hal-01920843 \\ https://hal.science/hal-01920843}

Submitted on 28 Dec 2020

HAL is a multi-disciplinary open access archive for the deposit and dissemination of scientific research documents, whether they are published or not. The documents may come from teaching and research institutions in France or abroad, or from public or private research centers.
L'archive ouverte pluridisciplinaire HAL, est destinée au dépôt et à la diffusion de documents scientifiques de niveau recherche, publiés ou non, émanant des établissements d'enseignement et de recherche français ou étrangers, des laboratoires publics ou privés. 


\title{
A comprehensive phylogeny of the gundis (Ctenodactylinae, Ctenodactylidae, Rodentia)
}

\author{
Raquel López-Antoñanzas \& Fabien Knoll \\ Departamento de Paleobiología, Museo Nacional de Ciencias Naturales-CSIC, c/ José \\ Gutiérrez Abascal 2, Madrid 28006, Spain. E-mails (RLA): ralopan@mncn.csic.es; (FK): \\ knoll@mncn.csic.es
}

\begin{abstract}
The subfamily Ctenodactylinae is known from the Early Miocene up to the present. Today, this group comprises five species, which are restricted to north and east equatorial areas in Africa. However, by Miocene times, the ctenodactylines experienced their greatest diversification and widest distribution from Asia, their land of origin, to Africa where they entered during the Middle Miocene at the latest. So far 24 species can be referred to this group: Ctenodactylus gundi, C. vali, Massoutiera mzabi, Felovia vae, Pectinator spekei, Pellegrinia panormensis, Sayimys obliquidens, S. baskini, S. giganteus, S. assarrarensis, S. intermedius, S. sivalensis, Metasayimys curvidens, Africanomys pulcher, A. major, A. minor, A. kettarati, Irhoudia bohlini, I. robinsoni, Pireddamys rayi, Sardomys dawnsonae, S. antoniettae, Akzharomys mallos, and Prosayimys flynni. A cladistic analysis involving all the above-mentioned species has been carried out. P. flynni turned out to be the most basal species of the ingroup. The genus Sayimys did not appear monophyletic. This analysis also provided information about the origin of not only the African ctenodactylines, which is to be found in the Indian subcontinent, but also of the European ones: Asiatic for the Sardinian species, but African for the Sicilian ones.
\end{abstract}

Keywords: Mammalia; Systematics; Cladistics; Cenozoic; Eurasia; Africa 


\section{Introduction}

The Ctenodactylidae Gervais, 1853 (as Ctenodactylina) is a family of rodents with hystricomorphous skulls and sciurognathous lower mandibles. This family comprises four subfamilies: the Tataromyinae Lavocat, 1961, the Karakoromyinae Wang, 1994, the Dystylomyinae Wang, 1994 and the Ctenodactylinae Gervais, 1853. The Karakoromyinae and Dystylomyinae went extinct during the Oligocene; the Tataromyinae, at the end of the middle Miocene. The only extant family is the Ctenodactylinae, which ranges from Early Miocene to Recent. It includes 22 species distributed in 14 genera. In the Miocene, the Ctenodactylinae experienced their greatest diversification and widest distribution, from northwestern Africa to northwestern India and central China (Fig. 1). The four extant genera (Pectinator, Massoutiera, Felovia, and Ctenodactylus) are restricted to areas in north and east equatorial Africa (Fig. 1).

Despite their rich evolutionary history, the phylogeny of the Ctenodactylinae has been the focus of very few studies. This is particularly unfortunate because the development of this group is intertwined with major paleoecologic perturbations such as the collision of Afro-Arabia with Eurasia in the Early Miocene and the birth of the Sahara desert in Late Miocene times. This motivated us to provide a substantiated hypothesis of the mutual relationships within the Ctenodactylinae based on cladistic methods.

\section{Material and methods}

The phylogenetic analysis presented below is based on the examination of original specimens, casts, and data from the literature. We examined the following: skulls of extant Massoutiera mzabi (71064, 71149, 71154, 71156, 71157, 71152, 71155, 71150,71158, 71161, 71163, 71164, 71151, 71162, 71159, 37735, 37736, 37737, 37738, 37739 in the MB and C.G.1960-3741, C.G.1959-93, C.G.1960-3812, C.G.1959-92, C.G.1989-29, C.G.1912-322, C.G.1953-381, C.G.1955-3, C.G.2000686 in the MNHN), Felovia vae (41239, 41242, 4124 in the MB and CG-1994-612, CG-1994-613, C.G.1995-3157 in the MNHN), Ctenodactylus gundi (15515, 15516, 71186, 25640, 37765, 1302, 71177, 71188, 71185, 20721, 2784, 71179, 71181, 71187, 71182 in the MB and C.G.1963-921, C.G.1975-303, C.G.1975-304, C.G.1975-305, C.G.1975-306, C.G.1975-307, C.G.1975-309, C.G.1975-308, C.G.1975-306, C.G.1975-304, C.G.1905-437, C.G.1991-1298, C.G.1991-1316, C.G.1993-1680, C.G.2007-329 in the MNHN), C. vali (C.G.1952-664, C.G.1952-666, C.G.1952668, C.G.1951-389, C.G.1953-787 in the MNHN), Pectinator spekei (26563, 71171, 71169, 71153, 
37977, A2636, 3935, 71165, 71166, 71167, 71175, 71170, 71172, 71174, 71173 in the MB and C.G.1895-461, C.G.1895-459, C.G.1895-460, C.G.1986-240, C.G.1978-263, C.G.1978-264, C.G.1978-265, C.G.1978-266, C.G.1978-267, C.G.1981-504, C.G.1960-3744, C.G.1960-3783 in the MNHN) isolated teeth, maxillary fragments and mandible fragments of the following extinct species: Prosayimys flynni (casts of Z295, Z307, Z317, Z312, Z308, Z309, Z311, Z313, Z310, Z316, Z294, Z292, Z287, Z289, Z293, Z290, Z306, Z296, Z291, Z305, Z288, Z303, Z304, Z297 in RLA's personal collection); Sayimys assarrarensis from Saudi Arabia (AS21-1023, AS21 1001, AS21 1002, AS8 1001, AS21 1008, AS8 1000, AS21 1005, AS21 1004, AS21 1018, AS21 1017, AS8 1003, AS21 1016, AS21 1024, AS21 1026, AS21 1028, AS8 1002, AS21 1025 in the MNHN); S. giganteus from Turkey (KSK1-100 to KSK1-102; KSK2-100 to KSK2-104; HJ-100 to HJ-108 in the MNHN); S. intermedius from Saudi Arabia (TMA 100, TMA 101 in the MNHN) and from Chios Island, Greece (THA91-01 to THA91-03, THA91-10 to THA91-14, THA91-21 to THA9125, THA91-28 to THA91-31; THA93-26, THA93-27, THA93-04 to THA93-09; THA93-15 to THA93-20, THA93-32 to THA93-36 in the MNHN); S. chinjiensis (= S. sivalensis) (casts of YGSP 634/45186, Y-GSP 634/45183, Y-GSP 634/45187 in RLA's personal collection); Metasayimys curvidens (Ben Mel 1357, Ben Mel 1353, Ben Mel 1354, Ben Mel 1371 in the MNHN), Africanomys pulcher (Ben Mel 1356; Ben Mel 1367, Ben Mel 1369 in the MNHN).

First, second, and third lower molars are designated as $\mathrm{m} 1, \mathrm{~m} 2$, and $\mathrm{m} 3$ respectively and first, second, and third upper molars as M1, M2, and M3. Lower and upper permanent premolars are designated as p4 and P4, respectively, and lower and upper deciduous premolars as dp4 and DP4. The terminology used in the tooth descriptions follows the rodent dental terminology of Baskin (1996) with some adjustments (see Fig. 2).

The cladistic analysis involves all extant and fossil species of this subfamily known to date. Karakoromys and Tataromys, basal ctenodactylid genera according to the phylogenetic analysis of Wang (1997), are selected as outgroup. The data matrix was built under Mesquite 2.6 (Maddison \& Maddison 2009) and the analysis was run in PAUP version 4.0b10 (Swofford 2001) using the PaupUp graphical interface (Calendini \& Martin 2005). Branch support was estimated through two complementary indices: Bremer Support and Relative Bremer Support. The first measures support of a clade as the minimum length of suboptimal trees in which the clade is not fully supported by the data, collapsing in the strict consensus (Bremer 1994). The second expresses support as the percentage of favourable minus contradictory evidence for each clade (Goloboff \& Farris 2001). Both support indices were calculated in TNT (Goloboff et al. 2008).

\section{Abbreviations}


C. BR: Collection of Dr J. Braillon; C.G: Catalogue général; CM: Carnegie Museum of Natural History, Pittsburgh, USA; GSI, Geological Survey of India, Calcutta, India; FSO: Faculté des Sciences d'Oran, Algeria; Y-GSP: Yale-Geological Survey of Pakistan, Quetta, Pakistan; IVAU: Department of Earth Sciences, Utrecht, Netherlands. MB: Museum für Naturkunde der HumboldtUniversität, Berlin, Germany; MGONM: Muséum de Géologie Office National des Mines, Tunis, Tunisia; MNHN: Muséum national d'Histoire naturelle, Paris, France; MTA: Mineral Resources and Exploration, General Directorate, Natural History Museum, Ankara, Turkey; PMNH: Pakistan Museum of Natural History, Islamabad, Pakistan; NHMR: National Heritage Museum, Riyad, Saudi Arabia; PMAE: Peabody Museum of Archaeology and Ethnology, Cambridge, USA; PMU: Palaeontological Museum, University of Uppsala, Uppsala, Sweden; PUA: Panjab University, Chandigarh, India; PIN, Paleontological Institute of the Russian Academy of Sciences, Moscow, Russia; SGM: Geological service of Rabat, Morocco; UB: Üniversitat Bonn, Bonn, Germany; UM: Université des Sciences et Techniques du Languedoc, Montpellier, France; Z: Zinda Pir area, Pakistan.

\section{Systematics}

Ctenodactylids are distributed in northern and eastern Africa essentially in desert or semidesert terrain, where they dwell in caves or rocky crevices. As they are found in regions of arid or semiarid climate, the vegetation is sparse and they must forage over long distances and are opportunistic in their diet (they eat leaves, stalks, flowers, and seeds of almost any plant, but animal food is not known to be eaten). Misonne (1971: pp. 5-6) and Dieterlen (2005: pp. 1536-1537) have provided a census of valid extant species of ctenodactylids (see also Ellerman \& Morrison-Scott 1951: pp. 521522, 1966: pp. 521-522). They concluded that only five species exist at present: Ctenodactylus gundi, C. vali, Massoutiera mzabi, Felovia vae, and Pectinator spekei. This is widely acknowledged by mammalogists so we shall not reconsider their synonymies, which appear very reasonable and are beyond the scope of this paper. The morphology of the teeth of the living ctenodactylines was described in detail by Jaeger (1971). Therefore, in this work, we only give a short historical background for these four genera as well as some additional details. The mention of a possible Pliocene representative of Pectinator in Asia (see e.g. McKenna \& Bell 1997: p. 190) probably comes from Darlington (1957: p. 392). However, this was based on Hinton (1933) and is, therefore, incorrect (see below). Besides, based on the works of previous authors (Joleaud 1935, Arambourg 1949, 1952, Arambourg and Coque 1958), Le Houérou (1995: p. 60, 1997: p. 629) mentioned the presence of C. gundi at the Pliocene locality of Aïn Brimba (Tunisia). Nevertheless, none of the mentioned publications indicated the presence of Ctenodactylus at this locality (see also Coque 
1962) so that this record appears dubious. Jaeger (1975: p. 7) merely listed Ctenodactylidae indet. at this site. For extrinsic reasons (age), it is more likely that this material belongs actually to the fossil genus Irhoudia. In fact, the extant genera have been mentioned as known only from the Holocene (Wood 1977; Novak 1999: p. 1622). However, Ctenodactylus spp. has been cited recently from the Upper Pleistocene site of the Grotte des Pigeons (Taforal, Morocco) (Bouzouggar et al. 2007). Except for C. gundi from Redeyef (Table Sud and Table Redeyef, Gafsa, Tunisia) (Vaufrey 1955: 394) and M.mzabi from Ti-n-Torha (Tadrart Acacus, Libya) (Gautier \& van Neer 1982), no subfossil material of the extant genera has been found to date, which is probably due to a bias in the observational record.

\section{Genus Ctenodactylus Gray, 1830}

Type species. Ctenodactylus gundi (Rothman, 1776)

Ctenodactylus gundi (Rothman, 1776). Rothman (1776: p. 339) described the first ctenodactylid as Mus gundi, from a specimen coming from the Gharyan area (Lybia), about $80 \mathrm{~km}$ south-south-west of Tripoli. The brief Latin diagnosis he gave (Fig. 3) can be translated as follows: "Tail short. With all feet tetradactyl. All the body brick-reddish. Ears short, opening large, oval. First teeth excavated, upper teeth truncated, lower teeth pointed. All fingers with nails. Walking on the sole. Of smaller size than the rabbit". The present whereabouts of the original specimen are unknown; it is not in the Naturhistoriska Riksmuseet in Stockholm (U. Johansson, pers. comm., 2010). Thomas (1920) proposed the specimen BMNH 1855.12.24.128 as as provisional topotype of $C$. gundi. Gray (1830: p. 11) published the description of what he thought was an arvicolid as C. massonii. The two species were soon considered as the same (see e.g. Yarrell 1830), the North African gundi. C. gundi is found in some parts of Morocco, Algeria, Tunisia, and Libya (Fig. 1).

Ctenodactylus vali Thomas, 1902. C. vali, the desert gundi, is the latest validly named living ctenodactylid. The holotype specimen (BMNH 1902.11.4.76) is in the Natural History Museum (London). It comes from Wadi Bey (Libya), about $330 \mathrm{~km}$ south-east of Tripoli. It is found in some parts of Morocco, Algeria, and Libya (Fig. 1).

The specific distinctiveness of Ctenodactylus vali with regard to C. gundi has been rejected by Ellerman \& Morrison-Scott (1951) and some subsequent authors, who considered the former a subspecies of the latter. However, the differences between the two taxa, such as the morphology of the M3, which is L-shaped in C. gundi and kidney-shaped in C. vali, support specific distinction (George 1982). 


\section{Genus Massoutiera Lataste, 1885}

Type species. Massoutiera mzabi (Lataste, 1881)

Massoutiera mzabi (Lataste, 1881). In 1881, Lataste named the species Ctenodactylus mzabi, which he allocated to the new genus Massoutiera in 1885. The original material came from Ghardaïa (Algeria), about $480 \mathrm{~km}$ south of Algiers. The lectotype (Thomas 1919; P. Jenkins, pers. comm., 2010) consists of the skull (BMNH 1919.7.7.1311) and skeleton of the same specimen (BMNH 1957.3.19.2). The Mzab gundi has a large, though discontinuous, geographical range: central and south-western Algeria, eastern Mali, western Niger, and north-western Chad (Fig. 1). Its presence was mentioned from the prehistoric (c. 7.000 BC) site of Ti-n-Torha (Tadrart Acacus, Libya; Gautier \& van Neer 1982; Gautier 1987). The remains, which were merely identified on the basis of size and the distribution of extant ctenodactylids (incidentally, they were initially attributed to Ctenodactylus sp. in Cassoli \& Durante 1974), have been morphologically studied in detail by López-Antoñanzas \& Knoll (in review), which proved this asignation correct.

It is unusual to find premolars in the maxillae and mandibles of Massoutiera. This is especially true for the p4 to the point that Jaeger (1971: p. 117) was uncertain about its presence in this genus and gave the following dental formula to Massoutiera: I 1/1-P 1/?-DP4 1/1-M 3/3). However, specimens housed at the MNHN (CG. 1989-29, C.G. 1912-322, and C.G. 1953-381) show the lower and upper permanent premolars (Figs 4A and 4C). Thus, the dental pattern of Massoutiera is I 1/1-P 1/1-DP4 1/1-M 3/3. It seems to us that this taxon loses the $\mathrm{p} 4$ before the P4 (e.g. specimens M.B. 71164 and MNHN CG-1960-3741), which could explain the particular paucity of the p4 in Massoutiera. We have not seen deciduous premolars in this genus, but according to Jaeger (1971) the DP4 and dp4 are morphologically similar to the molars, but clearly smaller in size. The upper incisors of this taxon are usually smooth, but in some specimens they are very weakly grooved.

\section{Genus Felovia Lataste, 1886}

Type species. Felovia vae (Lataste, 1886)

Felovia vae (Lataste, 1886). The lectotype (Thomas 1919) consists of the skin (BMNH 1919. 7. 7. 3233) and skull (BMNH 1919. 7. 7. 3232) of an adult female individual. It is comes from around Felou (Senegal), about 380 km east-south-east from Dakar. The Felou gundi is confined to western Senegal, eastern Mali, and western Mauritania (Fig.1).

Originally described as belonging to Massoutiera within the new subgenus Felovia, this species indeed resembles M. mzabi. However, Felovia can be distinguished from it by its strongly grooved upper incisors, a feature distinguishing Felovia from all the remaining living ctenodactylid species 
as well. As is the case in Massoutiera, the p4 is not usually observed in the mandible of this taxon. Jaeger (1971: p. 117) thought that this tooth was absent. However, some specimens (as specimen number 41239 housed in the MB or MNHN C.G. 1995-3157, C.G. 1994-613) clearly show the sockets for this type of tooth (Fig. 4D). Therefore, the dental pattern of Felovia is no doubt the same as that of Massoutiera: I 1/1-P 1/1-DP4 1/1-M 3/3 (Figs 4B and 4D). Felovia and Massoutiera are more hypsodont than Ctenodactylus and Pectinator.

\section{Genus Pectinator Blyth, 1856}

Type species. Pectinator spekei Blyth, 1856

Pectinator spekei Blyth, 1856. The original specimen (which is supposed to be in the Indian Museum, Calcutta) was collected in the Laasqoray area (Somalia), about 1040 km north-north-east of Mogadishu. Besides Somalia, the Speke's gundi lives in Ethiopia, Djibouti, and Erythrea (Fig. 1), geographically isolated from the other gundis.

The dental morphology of this species, with three-lobed lower molars that lack cement filling in their valleys, clearly resembles that of Sayimys sivalensis (Fig. 5).

\section{Genus Pellegrinia De Gregorio, 1887}

Type-species. Pellegrinia panormensis De Gregorio, 1887

Pellegrinia panormensis De Gregorio, 1887. This species was erected by De Gregorio in 1887 on the basis of dental, cranial and postcranial remains found in Monte Pellegrino (near Palermo, northern Sicily). De Gregorio (1925) described later additional material of this species from the same site. Unfortunately, De Gregorio did not designate a type (nor did any latter author). The original material is housed in the Museo Geologico G. G. Gemmellaro in Palermo (C. Di Patti, pers. comm., 2010). Jaeger (1971) redescribed this species on the basis of some material housed in the collections of the Naturhistorisches Museum (Basel). In 1972, Thaler published the recovery of Pellegrinia at three localities in Monte Pellegrino, which he called Pellegrino-Vetta, PellegrinoFalde, and Pellegrino-Occidentale. The first one was the locality from which the material described by de Gregorio (1887) came. The localities of Monte Pellegrino have not been properly dated and are, therefore, a matter of controversy. Most of the authors considered them as late Pliocene or early Pleistocene in age (De Gregorio 1887; Jaeger 1971; Thaler 1972; Kotsakis 1986; Villa 2001; Azzaroli 1990; Agnesi et al. 2004; Marra 2005). However, they would be Early or Middle Pliocene in age according to Sondaar \& Van der Geer (2005). 


\section{Genus Sayimys Wood, 1937}

Type species. Sayimys perplexus Wood, 1937

Due to scarcity of fossils or their poor preservation, some records of Sayimys cannot be made at the species level. Thus, Sayimys sp. has been recorded from the Lower Miocene Anatolian localities of Horlak, Çatalarkac, and Yapinti (De Bruijn 1999; Sümengen et al. 1990; Ünay et al. 2001), from the Middle Miocene Greek locality of Antonios (Vasileiadou \& Koufos 2005) and from some Middle Miocene Pakistani localities in the Kamlial, Chinji, and Manchar formations (De Bruijn et al. 1989; Baskin 1996).

Sayimys obliquidens Bohlin, 1946. The holotype (T. b. 268 b) of this species (Bohlin 1946: p. 111, figs 30b, 30b', 30b') is a left lower jaw with p4-m3 (the lingual halves of p4 and m1 are missing) housed in the PMU. It comes from a horizon of the Tiejianggou Formation in Tabenbuluk region (Gansu, China). This horizon is different from the beds in which most of the micromammals were found at Taben-buluk (Bohlin 1946) and its age is controversial. Most authors assign it an Early Miocene age (e.g., Wang et al. 2003). However, a recent study of the Tabenbuluk vertebrate localities discovered by Bohlin suggests a possible Middle Miocene age for the strata with remains of S. obliquidens (Wang et al. 2008). Nevertheless, these authors are cautious in this assertion due to the scarcity of associated taxa and the possibility of a mixed fauna therein. In our opinion, the stage of evolution of S. obliquidens, which is among the most basal species of the Ctenodactylinae (e.g., for having a metalophulid II on the lower molars), suggests an Early Miocene in age.

One d4 considered as an $\mathrm{m} 1$ of Asiazapus ingens by Lopatin \& Zazhigin (2000), but belonging in fact to Sayimys obliquidens (López-Antoñanzas \& Sen 2004), has been found in the Lower Miocene Akzhar Formation of Batpaksunde (Eastern Kazakhstan). Elsewhere, Sayimys aff. obliquidens has been recorded in Kazakhstan from the Lower Miocene middle members of the Chul'adyr Formation of the Aktau Mountains (Kordikova \& De Bruijn 2001).

\section{Sayimys baskini López-Antoñanzas et Sen, 2003.}

Synonymy list

1981 Sayimys minor (partim) De Bruijn, Hussain and Leinders

1996 Sayimys cf. minor Baskin

López-Antoñanzas \& Sen (2003) argued that the species Sayimys minor De Bruijn, Hussain \& Leinders 1981 from the Lower Miocene Murree Formation of Pakistan is invalid because its holotype (one m1-2) was in fact an m1-2 of S. intermedius. It differs from the m1-2s of the early Middle Miocene Kamlial Formation of Pakistan tentatively referred to as Sayimys cf. minor (Baskin 1996, pl. 1G). Therefore, López-Antoñanzas \& Sen (2003) considered the nominal taxon S. minor 
as a junior synonym of $S$. intermedius and they coined the new species $S$. baskini for all the specimens of the Kamlial Formation together with two (d4 and m3) out of the four paratypic specimens of $S$. minor from the Murree Formation described by De Bruijn et al. (1981). Thus, the holotype of S. baskini (Y-GSP 747/48125) is a right P4 (Baskin 1996: fig. 4a) from the Lower Miocene locality Y 747 of the Kamlial Formation of the Potwar Plateau, Pakistan. There is additional material of this taxon from the locality Y 721 of the same Formation (Baskin 1996) as well as the specimens from the Lower Miocene Murree Formation in the Banda Daud Shah area in Pakistan (De Bruijn et al. 1981).

Sayimys giganteus López-Antoñanzas, Sen et Saraç, 2004. López-Antoñanzas et al. (2004) erected the new species Sayimys giganteus on the basis of some isolated cheek teeth and maxillary fragments from the Lower Miocene (MN3-MN4) Turkish localities of Keseköy and Hişarcik. The holotype (KSK1-100), a fragmentary left maxilla with P4-M1 is housed in the MTA (LópezAntoñanzas et al. 2004).

Sayimys assarrarensis López-Antoñanzas et Sen, 2004. The holotype of this species (AS211023), a fragmentary left maxilla with P4-M2 is housed in the MNHN and comes from the Lower Miocene locality of As-Sarrar, Saudi Arabia (López-Antoñanzas \& Sen 2004).

Sayimys intermedius (Sen et Thomas, 1979). This species was originally described by Sen and Thomas (1979) as Metasayimys intermedius. It was later assigned to the genus Sayimys (Munthe 1980 and subsequent authors). The holotype (AJ 545) is a fragmentary left mandible with p4-m2 from the Middle Miocene Hofuf Formation, Al Jadidah, Saudi Arabia (Sen \& Thomas 1979), which is housed in the NHMR. This species is also recorded in the likely MN5 age site of Tayma, northwestern Saudi Arabia (López-Antoñanzas \& Sen 2004). Beyond the Arabian peninsula, Sayimys intermedius is known in Pakistan from the Lower Miocene Murree Formation at Banda Daud Shah (as S. minor (De Bruijn et al. 1981)) and from the Middle Miocene Lower Manchar Formation at the Sind localities H-GSP 81.06, H-GSP 81.07, and H-GSP 81.14a (De Bruijn et al. 1989). In addition, ctenodactylid teeth from the early Middle Miocene (MN5) locality of Thymiana (Chios Island, Greece), Keramaria Formation, are identified as S. intermedius, despite slight differences from the Pakistani and Saudi Arabian representatives of this taxon (López-Antoñanzas et al. 2005). Finally, S. intermedius has been cited in the Lower Miocene (MN3a) Hatzeva Formation of the Rotem Basin, Israel (Goldsmith et al. 1982; Tchernov et al. 1987; Savage 1990; Wood \& Goldsmith 1998). However, this latter record cannot be confirmed until a thorough description and determination is available. Mein (2003: p. 408) was probably misled by De Bruijn (1999: p. 264) 
when he cited $S$. intermedius in Jebel Zelten (Libya). In fact, based on the illustrations provided by Wessels et al. (2003) and Fejfar \& Horáček (2006), it can be affirmed that the Libyan Miocene ctenodactylid is not $S$. intermedius, notably because of the presence of a metalopulid II and the absence of a distinct anteroconid on the dp4. According to Wessels et al. $(2003,2008)$ and Fejfar \& Horáček (2006), this material belongs in fact to a new species of Sayimys. The biostratigraphical distribution of S. intermedius is probably Lower-Middle Miocene (MN 3-MN6).

Sayimys cf. intermedius has been recorded in Pakistan from the early Middle Miocene Vihowa Formation of the Zinda Pir Dome and from the early Middle Miocene Kamlial Formation of the Potwar Plateau (Baskin 1996). A single worn and damaged tooth considered as Sayimys cf. intermedius has been recovered from the Oligocene Ulaan Tolgoi section UTO-A/3 (level D1), Valley of Lakes, Central Mongolia (Schmidt-Kittler et al. 2007). Sayimys cf. intermedius is also mentioned in the Middle Miocene Turkish locality of Paşalar (Flynn \& Jacobs 1990; PeláezCampomanes \& Daams 2002).

\section{Sayimys sivalensis (Hinton, 1933).}

Synonymy list

1937 S. perplexus Wood

1996 S. chinjiensis Baskin

Hinton (1933) coined this species as Pectinator sivalensis, giving a brief description and no illustration of it. Later on, Black (1972) illustrated, described, and transferred this taxon to the genus Sayimys. The holotype of this species (GSI D284) is a left dentary fragment with $\mathrm{m} 2$ and $\mathrm{m} 3$ from the Middle Miocene Chinji Formation, Pakistan (Hinton 1933). Though it was supposed to be kept in the collections of the University of Bristol, it might have been returned to the GSI (E.

Loeffler, pers. comm., 2010).

Sayimys perplexus Wood, 1937 (named as the type-species of the genus) is here considered a junior synonym of S. sivalensis in agreement with Munthe (1980), Wang (1997), and LópezAntoñanzas \& Sen (2003). However, this is a case of subjective synonymy and, therefore, the genus Sayimys should continue to be used (see discussion in Munthe 1980: p. 25). We agree with LópezAntoñanzas \& Sen (2003) in considering S. chinjiensis a junior synonym of S. sivalensis.

Sayimys sivalensis (including S. perplexus and S. chinjiensis) is known in Pakistan from the Middle Miocene Lower Manchar (De Bruijn et al. 1989), Kamlial (Baskin 1996), and Chinji Formations (Hinton 1933; Hussain et al. 1977; Munthe 1980; Dehm et al. 1982; Wessels et al. 1982; Baskin 1996). It is also known in India, from Ramnagar (Vasishat 1985) and from the Late Miocene of the Haritalyangar area (as S. perplexus Wood 1937; Prasad 1970; Vasishat 1978, 1985). 
Thus, the biostratigraphical distribution of S. sivalensis is probably Middle-Upper Miocene (MN5MN10).

Sayimys badauni Vasishat, 1985. The holotype of this species (PUA 74-70) is a left lower jaw with p4-m2 and i1, which is thought to come from the Tatrot Formation (Upper Siwaliks, India) (Vasishat 1985, pl. 24). S. badauni is the last record of Sayimys (c. 3.4 Ma). It was rivaled as a late survivor by the material from As Sahabi (two isolated teeth from P61A and a mandible fragment found by surface prospecting at P34A) in North Africa (Munthe 1982, 1987; Boaz 1996). However, As Sahabi may, in fact, be Late Miocene rather than Early Pliocene (see, e.g., Agustí 2008; Beyer 2008; Boaz et al. 2008). In addition, Baskin (1997: p. 42) pointed out that the ctenodactyline material from As Sahabi should be better referred to Africanomys, whereas it would belong to Irhoudia according to Agustí (2008).

The validity of the taxon Sayimys baudauni (Vasishat 1985) needs additional study. Its morphology strongly resembles that of Sayimys sivalensis, but the illustrations presented by Vasishat (1985) are not fully satisfactory (López-Antoñanzas \& Sen 2003). Therefore, this species is not included in our cladistic analysis.

\section{Genus Metasayimys Lavocat, 1961}

Type species. Metasayimys curvidens Lavocat, 1961

Synonymy

1961 Dubiomys Lavocat

\section{Metasayimys curvidens Lavocat, 1961.}

Synonymy list

1953 Sayimys Lavocat

1961 Sayimys jebeli Lavocat

1961 Africanomys incertus (partim) Lavocat

1961 Africanomys pulcher (partim) Lavocat

1961 Dubiomys mellali Lavocat

Lavocat (1961) based this species on two teeth from the Middle Miocene of Beni-Mellal, Morocco. He designated as holotype the specimen Ben. Mel. 35, which is now housed in the MNHN. Jaeger (1971) synonymized Africanomys pulcher (partim), A. incertus (partim), Sayimys jebeli, Metasayimys curvidens, and Dubiomys mellali, an action accepted by Wood (1977). However, Jaeger (1971), without explanation, rejected the species M. curvidens and created the combination M. jebeli to include all the above-mentioned species. Wood (1977) disagreed with this decision and 
pointed out that since $M$. curvidens was a valid name for the type species of the genus Metasayimys, the rules of the zoological nomenclature dictate that it must be the valid species. We agree with Wood (1977) in considering S. jebeli a junior synonym of M. curvidens.

Additional material of this taxon has been recovered from the Middle Miocene site of Jebel Rhassoul (Benammi 1997, 2006). The presence of Metasayimys cf. jebeli (=M. cf. curvidens) from the Middle Miocene locality of Pataniak 6 (Jebel Irhoud, Morocco) has been mentioned by Jaeger (1977). In addition, Benammi (2006) has identified Metasayimys aff. jebeli (=M. aff. curvidens) from the Middle Miocene localities of Azdal 1 and 3 (Ait Kandoula, Morocco).

\section{Genus Africanomys Lavocat, 1961}

Type species. Africanomys pulcher Lavocat, 1961

\section{Africanomys pulcher Lavocat, 1961.}

Synonymy

1961 Africanomys incertus (partim) Lavocat

The holotype of this species (Ben. Mel.1375) is a right DP4 from the Middle Miocene of BeniMellal that is housed in the MNHN. Jaeger (1971) synonymized Africanomys incertus (partim) with A. pulcher, an action with which we agree. Additional material of this taxon has been recovered from the Middle Miocene site of Jebel Rhassoul, Morocco (Benammi 1997, 2006). Furthermore, the presence of Africanomys cf. pulcher has been mentioned by Benammi (2006) from the Middle Miocene localities of Azdal 1 and 3 (Aït Kandoula, Morocco).

Africanomys major Jaeger, 1977. This species was defined on the basis of 14 isolated dp4, 28 mandible fragments and 18 maxillary fragments from the Pataniak 6 locality in Jebel Irhoud, Morocco (Jaeger 1977). This locality has been considered Middle Miocene in age (Benammi et al. 1996). Its holotype (P6-141) is a mandible fragment with p4-m3 housed in the SGM (Jaeger 1977). Additional material of this taxon has been recovered from the Upper Miocene of Sheikh Abdallah, Egypt (Heissig 1982; Wanas et al. 2009).

\section{Africanomys minor Jaeger, 1977.}

Synonymy

1961 Africanomys aff. pulcher Lavocat in Jaeger 1974

Africanomys minor was coined and described in 1977 by Jaeger on the basis of 60 maxillary fragments, 54 mandibular fragments, 16 isolated dp4, and 8 isolated $\mathrm{m} 3$ from the Middle Miocene Pataniak 6 locality (Jebel Irhoud, Morocco). The holotype of this species (P6-84) is a mandible 
fragment with m1-m3, housed at the collections of the SGM (Jaeger 1977). Additional material of this taxon has been recovered from the Upper Miocene of Sheikh Abdallah, Egypt (Heissig 1982), but according to Wanas et al. (2009) this material could be A. kettarati.

Africanomys kettarati Jaeger, 1977. This species was defined on the basis of 6 isolated teeth from the Upper Miocene Oued Zra locality (Middle Atlas), Morocco. Its holotype (OZ-36) is an isolated M1-M2 housed in the SGM (Jaeger 1977). Additional material of this species has been recovered from the Upper Miocene Bou Hanifia 5, Algeria (Ameur 1984).

\section{Genus Irhoudia Jaeger, 1971.}

Type species. Irhoudia bohlini Jaeger, 1971

Remains of Irhoudia sp. have been found from the Upper Miocene locality of Amama 1, Algeria (Jaeger 1977) and from the Miocene/Pliocene site of Lissasfa, Casablanca, Morocco (Geraads 1998; Geraads 2002). Recently, Agustí (2008) pointed out on the basis of new material recovered from the Late Miocene of As Sahabi that the ctenodactyline remains from this site would pertain in fact to Irhoudia and not to Sayimys as suggested by Munthe (1982,1987), but neither description nor photographs of these remains were provided. In addition, Agustí (2008) remarked that these specimens retain a primitive DP4 as is the case in Africanomys. This observation is in agreement with the suggestion of Baskin (1997: p.42), who considered the material from As Sahabi as belonging to Africanomys. Actually, the As Sahabi ctenodactyline teeth described and figured by Munthe (1987) appear different from those of Irhoudia spp. (they are less hypsodont, show a posterobuccal cingulum, their protoconid is not hypertrophied...), which precludes their assignment to this genus.

Irhoudia bohlini Jaeger, 1971. This species was described and illustrated by Jaeger (1971) based on some isolated teeth as well as maxillary fragments from the Lower Pleistocene of Jebel Irhoud, Morocco. The holotype is an isolated $\mathrm{ml}$, which is currently housed in the UM. Irhoudia aff. bohlini has been described from the Upper Pliocene of Ahl al Oughlam, Casablanca, Morocco (Geraads 1985).

Irhoudia robinsoni Jaeger, 1977. This species was named on the basis of 34 isolated cheek teeth from the Upper Miocene (c. 7.5 Ma) locality of Amama 2, Algeria (Jaeger, 1977: p. 93). Its holotype, one $\mathrm{m} 1$ or $\mathrm{m} 2$ (A2-14), is kept in the collections of the FSO. 
Type species. Testouromys solignaci Robinson et Black, 1973

Testouromys solignaci Robinson et Black, 1973. This species was named on the basis of a single first upper molar (T-3724) and a broken first lower molar (T-3802) from the Middle Miocene of Testour Beja, Tunisia. This material is currently housed in the MGONM. We agree with De Bruijn et al. (1989) in considering this material insufficient to define a new genus and species. In addition, the same locality yielded a M3 of a species of Africanomys, which is larger and more hypsodont than A. pulcher from Beni Mellal according to Robinson \& Black (1973). Specimens T-3724 and T3802 might belong to the genus Africanomys. Therefore, due to the scarcity of this material and the dubious validity of this taxon, we do not take it into account in our phylogenetic analysis.

\section{Genus Pireddamys De Bruijn et Rümke, 1974}

Type species. Pireddamys rayi De Bruijn et Rümke, 1974

Pireddamys rayi De Bruijn et Rümke, 1974. The holotype (O.S. 142) of this taxon, a right mandible with p4-m3 and the incisor, was found at the Lower Miocene Oschiri road cut locality, Sardinia, Italy (De Bruijn \& Rümke 1974). The holotype is housed in the IVAU. This species is larger than all other ctenodactylid species, except for Sardomys dawnsonae. It differs from Sayimys spp. Metasayimys spp., and Africanomys spp. not only by its much greater size, but also by having deeply grooved incisors and by the presence of mesolophids on the lower molars. In addition, it differs from the species belonging to the genus Sardomys in lacking crown cement on the molars.

\section{Genus Sardomys De Bruijn et Rümke, 1974}

Type species. Sardomys dawnsonae De Bruijn et Rümke, 1974

Sardomys dawnsonae De Bruijn et Rümke, 1974. The holotype of this species (O.S.131) is a mandible with dp4-m3 from the Lower Miocene Oschiri road cut locality (De Bruijn \& Rümke 1974). The holotype is stored in the IVAU. This species is the largest member of the whole family known to date. It has semi-hypsodont molars and it differs from all Prosayimys, Sayimys, and Africanomys species in having crown cementum in both the lingual and labial folds of the $\mathrm{m} 2$ and the $\mathrm{m} 3$. The anterior face of the lower incisor is almost flat except for a shallow central longitudinal groove. The upper incisor has a deep central longitudinal groove.

Sardomys antoniettae De Bruijn et Rümke, 1974. The holotype of Sardomys antoniettae (O.S. 144), a mandible fragment with p4-m1, was recovered from the Lower Miocene Oschiri road cut 
locality (De Bruijn \& Rümke 1974). The holotype of this species is housed in the collections of the IVAU. S. antoniettae is larger than any other fossil ctenodactyline species except for S. dawnsonae, which is much larger.

\section{Genus Akzharomys Shevyreva, 1994}

Type-species. Akzharomys mallos Shevyreva, 1994

Akzharomys mallos Shevyreva, 1994. This species was defined by Shevyreva (1994) on the basis of four isolated teeth (one M1, one M2, one m1, and one m3) from the Lower Miocene of the Akzahr Formation (Kazhakstan). The holotype of this taxon (PIN no 3462/724) is a right M2. No additional material of this taxon has been found so far.

\section{Genus Prosayimys Baskin, 1996}

Type species. Prosayimys flynni Baskin, 1996

Prosayimys flynni Baskin, 1996. The holotype of $P$. flynni (Z113/295) comes from the upper part of the Chitarwata Formation in the Dalana section of the Zinda Pir Dome, Pakistan. Its age is constrained to Late Oligocene or possibly earliest Miocene (23 Ma), but cannot be determined definitively by the limited paleomagnetic evidence (Lindsay et al., 2005). The Prosayimys material is currently housed at the PMAE. It should eventually be returned to Pakistan and would be deposited at the PMNH (L. Flynn, pers. comm., 2002).

\section{Phylogenetic analysis}

\section{Previous works}

George (1979). George (1979) tried to decipher the relationships within the extant ctenodactylids based on their karyotypes. With this end in view, she calculated an index of dissimilarity based on differences in chromosome length and centromere position.

On the basis of George's (1979) dissimilarity indices, we constructed a distance matrix (Appendix 1) that could be processed in QuickTree (Howe et al. 2002) via the Mobyle server (http://mobyle.pasteur.fr/cgi-bin/portal.py). The Newick format tree file generated was visualized in the same platform through Drawtree (Felsenstein 2005). The resulting unrooted phenogram (Fig. 6A) showed the shorter distance between Pectinator spekei and Ctenodactylus gundi. The latter would be in fact closer to Ctenodactylus vali than to Pectinator spekei according to the George 
(1979) indices, but this last taxon was not included in the present analysis due to incomplete data. Massoutiera mzabi and Felovia vae are closer to one another than to the other two taxa. As F. vae and $C$. gundi are the farthest apart, the mid-point rooting method gave a phenogram with the following topology: ((P. spekei, C. vali) (M. mzabi and F. vae)).

George (1985). George (1985) conducted the first cladistic analysis of ctenodactylids. She included all five extant species and considered 28 characters from a diversity of fields (gross anatomy, physiology, karyotype, behaviour, etc.). She noted that "the decision about the derived apomorphic status or the plesiomorphic status of each character was based on fossil evidence where possible or by comparing the character with its state in other mammals" (George, 1985: p. 56) and she added that the cladogram was "constructed as a result of decisions (some of them arbitrary) on the status [of these characters]" (George, 1985: p. 58).

George (1985) found a single, fully resolved most parsimonious tree in which Pectinator spekei is the sister group to a symmetrical clade comprising Felovia vae and Massoutiera mzabi on the one hand and the two Ctenodactylus species on the other (Fig. 6C).

Lopez-Antoñanzas et al. (2004). In the course of the description of Sayimys giganteus, LopezAntoñanzas et al. (2004) offered a complement to previous work (Lopez-Antoñanzas \& Sen 2004) by conducting a cladistic analysis of all the valid species of Sayimys, Prosayimys, and Metasayimys. The data matrix of 19 characters was processed with PAUP version 3.1.1 (Swofford 1993), using the exhaustive search option, and thereby generated five equally most-parsimonious trees whose majority rule consensus solution is shown in Fig. 6B.

Apart from sister-species relationships between Sayimys obliquidens and S. giganteus, the topology is perfectly asymmetrical from the most basal taxon, Prosayimys flynni, to the most derived dyad: (S. intermedius, S. sivalensis).

Wible et al. (2005). In the course of the study of a new Eocene ctenodactyloid rodent, Exmus mini, Wible et al. (2005) evaluated through a cladistic analysis the relationships of this species to other ctenodactyloids and of ctenodactyloids to other Eocene rodents. Both dental and cranial characters were considered (the former representing a little less than $40 \%$ of the character list). Three ctenodactyline genera were included in the ingroup: Sayimys, Ctenodactylus, and Pectinator. The scoring of Ctenodactylus was based on C. gundi: specimens SSLG Nr. 519 (UB) for incisor enamel characters (from Martin 1992) and CM 45490 and 79249 for all the remaining characters. That of Sayimys was based on the specimen of S. sivalensis SSLG Nr. 632 (UB) for the 2 incisor enamel characters (from Martin 1992), but the remaining 102 dental and cranial characters were based on $S$. 
obliquidens (from Bohlin 1946). Inasmuch as all ctenodactylines are believed to have the same incisor enamel microstructure (multiserial HSB; Martin 1992, 1993, 1995; see also Bohlin 1946: pp. 143-146, pl. 4, figs 1-3), the composite coding of Sayimys in Wible et al. (2005) is effectively that of S. obliquidens.

According to Wible et al. (2005), a PAUP* 4.0b10 (Swofford 2002) heuristic running (stepwiseaddition) of their matrix, with 13 out of 23 multistate characters ordered, resulted in two most parsimonious trees. The strict consensus of these trees showed resolved intrarelationships of the three ctenodactylines (Fig. 6D), with Ctenodactylus as sister-taxon to (Sayimys, Pectinator).

\section{New analysis}

Terminal taxa. The taxonomic units chosen are all the valid species of ctenodactyline rodents (see above), namely Ctenodactylus gundi, C. vali, Massoutiera mzabi, Felovia vae, Pectinator spekei, Pellegrinia panormensis, Sayimys obliquidens, Sayimys baskini, Sayimys giganteus, Sayimys assarrarensis, Sayimys intermedius, Sayimys sivalensis, Metasayimys curvidens, Africanomys pulcher, Africanomys major, Africanomys minor, Africanomys kettarati, Irhoudia bohlini, I. robinsoni, Pireddamys rayi, Sardomys dawnsonae, Sardomys antoniettae, Akzharomys mallos, and Prosayimys flynni. They have been entered in the character/taxon matrix (Appendix 2) in approximate chronostratigraphic order.

Character polarity and rooting. According to the analysis performed by Wang (1997), the subfamily Distylomyinae (Prodistylomys, Distylomys) is the sister group of the Ctenodactylinae. Therefore, it would seem appropriate to choose one of these two genera as the outgroup of the Ctenodactylinae. However, when Wang (1997) performed her analysis, the distylomyines were very poorly known. Since then, new material has been described, which allowed Bi et al. (2009) to suggest that these rodents may be closer to the hystricognathous South American Cephalomys than to the ctenodactylids. Pending the resolution of the relationships of Distylomys and related taxa with the ctenodactylids, it is better to choose another outgroup. Therefore, Karakaromys decessus and Tataromys plicidens (two non-ctenodactyline ctenodactylid rodents) have been selected instead to give a direction to the character transformation and an order of reading of the successive branchings of the tree. Based on the results of the phylogenetic analysis of Dashzeveg \& Meng (1998) and the fact that the monophyly of the ingroup is not problematic (see e.g. Wang 1997), we have constrained $K$. decessus and T. plicidens to form a paraphyletic grouping (with the former species in the basalmost position) with respect to the ingroup. 
Characters, character weighting and transformation weighting. A total of 39 phylogenetically informative dental characters have been coded (Appendix 3). 19 characters are binary, whereas 20 are multistate. All the latter characters have two derived states. Owing to the lack of a priori information, all characters were unordered and equally weighted (Fitch optimality criterion).

Procedure. The data matrix was built under Mesquite 2.6 (Maddison \& Maddison 2009) and the analysis was run in PAUP version 4.0b10 (Swofford 2002) using the PaupUp graphical interface (Calendini \& Martin 2005). The relatively high number of terminal taxa and characters precluded exact tree building, so a branch and bound search was performed.

Results. Nine most parsimonious trees were generated with a length of 127 and a relatively high degree of homoplasy $(\mathrm{CI}=0.4567$ and $\mathrm{RI}=0.7305)$. The strict and semi-strict consensus trees are identical and largely resolved (Fig. 7A) with one polytomy involving Metasayimys curvidens, Africanomys spp., and the more derived ctenodactylines. The majority-rule consensus tree is completely resolved (Fig. 7B). As some species are known so far from only a few specimens, the influence of intraspecific variation in the scoring of the characters could not be assessed. Bremer and relative Bremer support indices (Goloboff \& Farris, 2001) for the clades in the analysis are listed on the cladogram in the figure 7A.

The transformations supporting the topology of this tree (under the ACCTRAN and DELTRAN optimizations) are listed in Table 1. Each internal node is discussed below, beginning from the most inclusive.

Node 49. Prosayimys flynni + more derived taxa. This node is supported by seven exclusive synapomorphies both under ACCTRAN and DELTRAN optimizations (metaconid connected to the metalophulid II and to the protoconid, anteroconid present on the dp4, moderate postero-labial ledge on the m1-m2, hypoflexid in front of the hypolophid on the lower molars, well developed anteroloph on the $\mathrm{P} 4$, presence of the lingual re-entrant fold on the $\mathrm{P} 4$, and deep hypoflexus on the M1-M2) and one more under DELTRAN (reduced P4).

Node 48. Sayimys obliquidens + more derived taxa. This node is supported by two exclusive synapomorphies both under ACCTRAN and DELTRAN (Y-shaped p4 and presence of the posterolabial ledge on the p4) and one more under ACCTRAN (transverse hypolophid on the dp4).

Node 47. Akzharomys mallos + more derived taxa. This node is supported by one exclusive synapomorphy under ACCTRAN: DP4 with short metaflexus.

Node 46. Sayimys giganteus + more derived taxa. This node is supported by two exclusive synapomorphies both under ACCTRAN and DELTRAN (metalophulid II absent on the lower 
molars and short metaflexus on the M1-M2) and one additional under DELTRAN (short metaflexus on the DP4).

Node 45. Sayimys assarrarensis + more derived taxa. This node is based on one ambiguous synapomorphy both under ACCTRAN and DELTRAN (posterolophid bended towards the entoconid on the m1-m2: a parallelism with S. obliquidens and Africanomys major) and one more under ACCTRAN (small size: a reversal with respect to node 46).

Node 44. Sayimys intermedius + more derived taxa. This node is based on one ambiguous synapomorphy: mesoflexid equal or longer than the metaflexid on the lower molars (a reversal with respect to node 48).

Node 43. Sardomys antoniettae + Pireddamys rayi + S. dawnsonae + more derived taxa. This node is based on two exclusive synapomorphies both under ACCTRAN and DELTRAN: length of the $\mathrm{m} 2$ smaller than that of the $\mathrm{m} 3$ and the M3 with reduced posterior lobe.

Node 42. Sardomys antoniettae + Pireddamys rayi + S. dawnsonae. This node is supported by four ambiguous synapomorphies both under ACCTRAN and DELTRAN : intermediate size, a parallelism with respect to Africanomys major and nodes 36 and 47 (only under the ACCTRAN optimization); four-lobed m1-m2 (a reversal with respect to node 47); metalophulid II on the m1$\mathrm{m} 2$ (a reversal with respect to node 46); postero-labial ledge absent on the $\mathrm{m} 1-\mathrm{m} 2$ (a reversal with respect to node 49) and one more under DELTRAN (oblique hypolophid on the m1-m2).

Node 41. Pireddamys rayi + Sardomys dawnsonae. This node is supported by two ambiguous synapomorphies both under ACCTRAN and DELTRAN: large size (parallelism with Pellegrinia panormensis) and semihypsodont teeth (parallelism with Africanomys minor and Irhoudia robinsoni).

Node 40. Sayimys sivalensis + more derived taxa. This node is supported by three exclusive synapomorphies both under ACCTRAN and DELTRAN (anteroloph weak or absent on the P4 (a reversal with respect to node 49), posteroloph weak or absent on the P4, paraflexus absent on the M1-M2) and one additional under DELTRAN (three-lobed M1-M2).

Node 39. Sayimys baskini + more derived taxa. This node is supported by one exclusive synapomorphy under ACCTRAN: the presence of a short paraflexus on the DP4.

Node 38. Metasayimys curvidens + more derived taxa. This node is supported by two exclusive synapomorphies under ACCTRAN optimization (very reduced p4 and P4) and one under DELTRAN (very reduced p4).

Node 37. Africanomys kettarati + A. minor + A. major + A. pulcher + more derived taxa. This node is based on one exclusive synapomorphy both under ACCTRAN and DELTRAN: absence of the anteroconid on the dp4 (a reversal with respect to node 49). 
Node 36. Pectinator spekei + more derived taxa (crown-group). This node is supported by four exclusive synapomorphies under ACCTRAN (very early disappearance of the metaflexus and paraflexus on the DP4, two-lobed M1-M2 and metaflexus absent on the M1-M2) and one under DELTRAN (metaflexus absent on the M1-M2).

Node 35. Irhoudia bohlini + I. robinsoni + more derived taxa. This node is based on four exclusive synapomorphies both under ACCTRAN and DELTRAN: hypsodont teeth, short metaflexid, hypertrophy of the protoconid on the m1-m2, and hypoflexid in front of the mesoflexid on the m1-m2 (a reversal with respect to node 49).

Node 34. Irhoudia bohlini + I. robinsoni. This node is based on three ambiguous synapomorphies under ACCTRAN (DP4 with a short metaflexus (a reversal with respect to node 36), DP4 with a long paraflexus (a reversal), and hypertrophy of the protocone on the M1-M2 (a parallelism with node 30)) and two under DELTRAN (hypertrophy of the protocone on the M1-M2 (a parallelism with node 30) and two-lobed M1-M2 (a parallelism with Pectinator spekei and Pellegrinia panormensis)).

Node 33. Ctenodactylus gundi + C. vali + more derived taxa. This node is supported by four exclusive synapomorphies both under ACCTRAN and DELTRAN (ever-growing teeth, reduced $\mathrm{dp} 4$, absence of the hypolophid on the dp4, two-lobed m1-m2).

Node 32. Ctenodactylus gundi $+C$. vali. This node is based on one exclusive synapomorphy both under ACCTRAN and DELTRAN (absence of the hypoflexus on the M1-M2).

Node 31. Pellegrinia panormensis + more derived taxa. This node is based on three ambiguous synapomorphies under ACCTRAN and two under DELTRAN (oblique hypolophid on the m1-m2 (a reversal with respect to node 39), valleys of the $\mathrm{m} 2$ and $\mathrm{m} 3$ filled with cement (a parallelism with Metasayimys curvidens and Sardomys dawsonae; only under ACCTRAN), and those of the upper molars as well (a parallelism with M. curvidens).

Node 30. Massoutiera mzabi + Felovia vae. This node is based on one exclusive synapomorphy under both ACCTRAN and DELTRAN (hypertrophied protocone on the M1-M2 (a parallelism with the node 34)) and one additional under DELTRAN (oblique hypolophid on the m1-m2 (a parallelism with Sayimys obliquidens, S. sivalensis, Pectinator spekei, and the node 42)).

Node 29. Africanomys kettarati + more derived taxa. This node is based on four ambiguous synapomorphies under ACCTRAN (metaconid located on the anterior edge of the dp4 (a parallelism with node 33 ), $\mathrm{m} 2$ similar in length to the $\mathrm{m} 3$ (a reversal with respect to node 43 ), reduced p4 (a reversal with respect to node 38), and posteroloph longer than the anteroloph on the P4 (a reversal with respect to node 40)).

Node 28. Africanomys minor + more derived taxa. This node is based on three ambiguous synapomorphies under DELTRAN (metaconid located on the anterior edge of the dp4 (a parallelism 
with node 33), $\mathrm{m} 2$ similar in length to the $\mathrm{m} 3$ (a reversal with respect to node 43), and P4 with the posteroloph longer than the anteroloph (a reversal with respect to node 40)).

Node 27. Africanomys major + A. pulcher. This node is based on two ambiguous synapomorphies under both ACCTRAN and DELTRAN (a reduced p4 (a reversal with respect to node 38) and the presence of a posterolophid on the p4 (a parallelism with node 47 under ACCTRAN and with node 46 under DELTRAN)).

\section{Discussion}

\section{Position of Prosayimys flynni}

Prosayimys flynni is the most basal species of the ingroup. As suggested by Baskin (1996), LópezAntoñanzas \& Sen (2004), and López-Antoñanzas et al. (2004) this genus can be seen as ancestral to Sayimys. Contrary to the opinion of Kordikova \& De Bruijn (2001: p. 398), Prosayimys should not be considered a synonym of Sayimys.

\section{Non-monophyly of the genus Sayimys}

López-Antoñanzas \& Sen (2004) and López-Antoñanzas et al. (2004) pointed out that in order to test the monophyly of the genus Sayimys a complete phylogenetic analysis involving all the species belonging in Ctenodactylinae had to be performed. One of the most interesting results of the present work is that the genus Sayimys does not appear monophyletic.

The earlier studies suggested that Sayimys giganteus and S. obliquidens, on the one hand, and S. intermedius and S. sivalensis, on the other, were sister-species. The present work does not confirm this topology, but rather advocates sister-group relationships between $S$. obliquidens and the clade composed of Akzharomys mallos and more derived ctenodactylines (of which S. giganteus is the most basal species). S. intermedius nests as the sister-species of the Sardomys-Pireddamys clade and more derived ctenodactylines (of which S. sivalensis is the most basal species).

With regard to Sayimys obliquidens, Jaeger (1971) and De Bruijn et al. (1981) advocated that this taxon is morphologically very close to Metasayimys curvidens. Jaeger (1971) thought that this species should be reallocated to the genus Metasayimys. Robinson \& Black (1973) agreed with Jaeger (1971) in considering S. obliquidens as close to Metasayimys and not belonging to Sayimys, but they felt it was "premature" to assign it to the former genus. In contrast, Wood (1977) agreed with Bohlin (1946) that $S$. obliquidens belonged in Sayimys. He thought that this species was closely related with $S$. perplexus (=S. sivalensis; see López-Antoñanzas \& Sen 2003), but not with M. curvidens. In addition, De Bruijn et al. (1981) suggested that due to the morphological similarity between the Chinese S. obliquidens and the African Metasayimys curvidens, the African 
ctenodactylines may have descended from a Central Asiatic form rather than from an ancestor that dwelled in the Indian subcontinent. However, S. obliquidens is far from being close (phylogenetically speaking) to M. curvidens. Actually, the African ctenodactylines (M. curvidens and the more derived species but Pellegrinia panormensis) are closely related to the Pakistani $S$. sivalensis and S. baskini (see below) and, therefore, their immediate ancestor is likely to be found in the Indian subcontinent.

In his comprehensive study of the evolution of the ctenodactylids, Wood (1977) suggested that Sayimys sivalensis was closer to Metasayimys than to S. obliquidens and should be placed in the genus Africanomys. Munthe (1980) proposed a phylogenetic sequence proceeding from $S$. obliquidens through S. sivalensis to Metasayimys and argued in favour of an independent origin for the genus Africanomys. De Bruijn et al. (1989) and Baskin (1996) advocated that Metasayimys had derived from $S$. minor (=S. baskini). Our analysis gives $S$. sivalensis a sister-species position to the clade comprising S. baskini and the more derived taxa. S. baskini, as the sister-species of the clade comprising $M$. curvidens and the more derived taxa, is very close to Metasayimys. Therefore, our result is in concordance with De Bruijn et al. (1989) and Baskin (1996), but also with Wood (1977) and Munthe (1980) who could not take into account S. baskini, which was published later. However, the transfer of S. sivalensis to Africanomys suggested by Wood (1977) is not justified. More recently, Kumar \& $\operatorname{Kad}$ (2002: p. 739) suggested that S. minor (S. baskini) is a plesiomorphic taxon of the lineage leading to $S$. sivalensis, but according to our results the reverse is correct.

\section{The Oschiri ctenodactylines}

The Lower Miocene species of ctenodactylines from Sardinia form a clade. The topology of the tree suggests that they may be all best seen as members of a single genus (Sardomys). However, due to the scarcity of available material of $S$. antoniettae, its classification in the genus Sardomys is open to discussion (De Bruijn \& Rümke 1974). If indeed S. antoniettae turns out to be morphologically distant from the type-species of the genus (S. dawsonae), it could then be reallocated to a genus of its own and Pireddamys be saved.

De Bruijn \& Rümke (1974) assumed that the ctenodactylids migrated from Asia to Sardinia through Africa, an opinion with which some authors agreed (Azzaroli \& Guazone 1979). Wood (1977) advocated that Sardomys and Pireddamys could have been derived from ancestors similar to the Asiatic Oligocene Karakoromys and Tataromys and suggested that the ctenodactylids might have reached Sardinia from a source distinct from North Africa. Later on, De Bruijn (1999) proposed an Early Oligocene migration from an Asiatic Kakaromyinae (like Bounomys or Euryodontomys) that reached as far West as Sardinia. Kotsakis \& Palombo (2009) did not discard this possibility. To test the relationships of Sardomys and Pireddamys with kakaromyines, we reran 
our analysis with $T$. plicidens alone as outgroup (KarakoK. decessus being added into the ingroup). $K$. decessus appears then as the most-basal species of the ingroup being sister-species of the clade comprising Prosayimys flynni and the more derived ctenodactyline taxa. The topology of the majority consensus tree is otherwise similar to that obtained in our original analysis. Therefore, the Oschiri ctenodactylines do not appear to have close relationships with Kakaromyinae. Our analysis hints in fact at an Asiatic origin of the Sardinian species, but a more recent one than postulated by De Bruijn (1999). It is likely actually that the ancestor of the Sardinian species is to be found in species similar to Sayimys intermedius that migrated during the earliest Early Miocene from Asia through the Hellenides, Dinarides, and northern Apennines to reach what would become Sardinia.

\section{The genus Africanomys}

Another interesting result is the evidence of the monophyletic nature of the genus Africanomys, which is the sister-group of the clade originating from the node 36 (the crown-group). According to Wood (1977), Africanomys was structurally ancestral to Metasayimys, but our results rather suggest that $M$. curvidens is more basal than Africanomys spp.

\section{The crown group}

Wood (1977) suggested that Pectinator spekei seemed derivable from Africanomys and Metasayimys, an opinion with which we agree. As defended by some authors (Jaeger 1971; George 1979, 1985), Pectinator spekei is the most basal of the living species of Ctenodactylinae. This taxon shares an exclusive common ancestor with the species of the Ihroudia clade and the more derived ctenodactylines.

According to De Bruijn \& Rümke (1974), Pellegrinia panormensis would have been a descendant of the Sardomys/Pireddamys branch rather than a Pleistocene immigrant from Africa as suggested by other authors (Thaler 1972; De Bruijn 1999; Villa 2001). However, our phylogenetic results are in line with the opinion of the latter authors: the origin of Pellegrinia panormensis is most probably African as this species is far from being connected to the other European representatives of the subfamily (that is the Oschiri species originating from the node 42).

Wood (1977) concluded that Pellegrinia was phylogenetically closer to Felovia and Massoutiera than to Irhoudia, which is more basal. This opinion is supported by our results. However, he considered that Irhoudia and Pectinator derived from an Africanomys-Metasayimys lineage and that Pellegrinia, Massoutiera and Felovia came from an independent lineage in which Sayimys obliquidens was basal. Actually, it turns out that Pectinator spekei and Irhoudia spp. constitute successively closer sister taxa to the clade constituted by Pellegrinia and the remaining extant ctenodactylines. Massoutiera mzabi and Felovia vae are sister species and they are closer to 
Pellegrinia panormensis than to the two species of Ctenodactylus. The very close relationship between Massoutiera and Felovia is not surprising due to their similar morphology. This result is in agreement with the analyses carried out by George $(1979,1985)$.

\section{Conclusion}

The most basal and oldest representative of the subfamily Ctenodactylinae is Prosayimys flynni from the Late Oligocene or earliest Miocene of Pakistan. The genus Sayimys, which is considered the most speciose and most widely distributed, is non-monophyletic.

The ctenodactylines provide a fine example of long distance dispersal of rodents consistent with geological evidence indicating the establishment of an Early Miocene corridor between Afro-Arabia and Eurasia (resulting from the collision of the Arabian Peninsula with the Anatolian plate). Even if the ctenodactylines are restricted to Africa at present, their phylogenetic relationships imply that the ancestry of these species is to be found in Asia. This subfamily underwent a wide geographic expansion during Miocene times, reaching Sardinia at the beginning of the Early Miocene and the north of Africa possibly in the Middle Miocene, through the Arabian Peninsula where the record of this subfamily dates as far back as the end of the Early Miocene. The origin of the European ctenodactylines is diverse; the Early Miocene Sardomys and "Pireddamys" from Sardinian have southwestern Asiatic origins, whereas the Sicilian Pleistocene Pellegrinia originated from an African ancestor. Interestingly enough, the ctenodactylines became extinct in Asia during the Pliocene and never returned from Africa.

\section{Acknowledgements}

We sincerely thank J. Cuisin and C. Sagne (Muséum National d'Histoire Naturelle, Paris) and F. Mayer and S. Jancke (Museum für Naturkunde der Humboldt-Universität, Berlin) for having made available the ctenodactylid material under their care and C. Di Patti (Museo Geologico G.G.Gemmellaro, Palermo), D. Geraads (CNRS UPR 2147, Paris), P. Jenkins (Natural History Museum, London), U. Johansson (Naturhistoriska Riksmuseet, Stockholm), E. Loeffler (University of Bristol, Bristol), and T. Martin (Universität Bonn, Bonn) for having answered our inquiries. J. Baskin (University-Kingsville, Kingsville) and L. Flynn (Harvard University, Cambridge) enhanced this work through carefull and critical reading. Our sojourn in Berlin was funded by the Alexander von Humboldt Foundation through sponsorships of renewed research stays in Germany. We are currently supported by the Ramón y Cajal Program and the research projects CGL2008-05813- 
CO2-01 directed by J. Morales (Museo nacional de Ciencias naturales-CSIC, Madrid) and CGL2009-12143 directed by one of us (F. K.).

\section{References}

Agnesi, V., Conoscenti, C. \& Di Patti, C. 2004. Monte Pellegrino. Pp. 21-25 in V. Agnesi, L. Bonfiglio, C. Ciurcina, C. Conoscenti, C. Di Maggio, C. Di Patti, G. Mangano, F. Masini, M. Pavia, D. Petruso \& U. Spigo (eds) 32nd International Geological Congress: Quaternary Eustatic Fluctuations and Biochronology of Vertebrate-bearing deposits correlated with marine terraces in Sicily. Volume 1. APAT, Roma.

Agustí, J. 2008. New Data on the Rodent Fauna from As Sahabi, Libya. Garyounis Scientific Bulletin, special issue 5, 139-143.

Ameur, R. 1984. Découverte de nouveaux rongeurs dans la formation Miocène de Bou Hanifia (Algérie occidentale). Geobios 17, 167-175.

Arambourg, C. 1949. Les gisements de Vertébrés Villafranchiens de l'Afrique du Nord. Bulletin de la Société géologique de France 14, 195-203.

Arambourg, C. 1952. La paléontologie des vertébrés en Afrique du Nord française. XIX ${ }^{\text {ème }}$ Congrès géologique international, Alger, 63 pp.

Arambourg, C. \& Coque, R. 1958. Le gisement villafranchien de l'Aïn Brimba (Sud-Tunisien) et sa faune. Bulletin de la Société géologique de France 8, 607-614.Azzaroli, A. 1990.

Palaeogeography of terrestrial vertebrates in the perityrrhenian area. Palaeogeography, Palaeoclimatology, Palaeoecology 77, 83-90.

Azzaroli, A. \& Guazone, G. 1979. Terrestrial mammals and land connections in the Mediterranean before and during the Messinian. Palaeogeography, Palaeoclimatology, Palaeoecology 29, 155167.

Baskin, J. A. 1996. Systematic revision of Ctenodactylidae (Mammalia, Rodentia) from the Miocene of Pakistan. Palaeovertebrata 25, 1-49.

Benammi, M. 1997. Nouveaux rongeurs du Miocene continental du Jebel Rhassoul (Moyenne Moulouya, Maroc).Geobios 30, 713-721.

Benammi, M. 2006. Nouveaux gisements à rongeurs dans le Miocène moyen continental du Bassin d'Ait Kandoula basin (Maroc). Geobios 39, 589-598.Benammi, M., Calvo, M., Prébot, M. \& Jaeger, J.-J. 1996. Magnetostratigraphy and paleontology of Ait Kandoula Basin (High Atlas, Morocco) and the African-European late Miocene terrestrial fauna exchanges. Earth and Planetary Science Letters 145, 15-29. 


\section{Benammi, M., Orth, B., Vianey-Liaud, M., Chaimanee, Y., Suteethorn, V., Feraud, G.,}

Hernandez, J. \& Jaeger, J.-J. 1995. Micromammifères et biochronologie des formations néogènes du flanc sud du Haut-Atlas marocain: implications biogéographiques, stratigraphiques et tectoniques. Africa Geoscience Review 2, 279-310.

Beyer, C. 2008. Establishment of a chronostratigraphical framework for the As Sahabi sequence in northeast Libya. Garyounis Scientific Bulletin, special issue 5, 59-69. Bi, S., Meng, J., Wu, W., Ye, J. \& Ni, X. 2009. New Distylomyid Rodents (Mammalia: Rodentia) from the Early Miocene Suosuoquan Formation of Northern Xinjiang, China. American Museum Novitates 3663, 1-18.

Black, C. C. 1972. Review of fossil rodents from the Neogene Siwalik Beds of India and Pakistan. Palaeontology 15, 238-266.

Blyth, E. 1856. Report on a zoological collection from the Somali country. Journal of the Asiatic Society of Bengal 24, 291-306

Boaz, N. T. 1996. Vertebrate palaeontology and terrestrial palaecology of As Sahabi and the Sirt Basin. Pp. 531-539 in M. J. Salem, A. J. Mouzughi \& O. S. Hammuda (eds) The geology of Sirt Basin. Volume 1. Elsevier, Amsterdam.

Boaz, N. T., El-Arnauti, A., Agustí, J., Bernor, R. L., Pavlakis, P. \& Rook, L. 2008. Temporal, lithostratigraphic, and biochronologic setting of the Sahabi Formation, North-Central Libya. Pp. 959-972 in M. J. Salem, A. El-Arnauti \& A. El-Sogher Saleh (eds) The Geology of East Libya, Sedimentary Basins of Libya. Volume 3. Earth Science Society of Libya, Tripoli.

Bohlin, B. 1946. The fossil mammals from the Tertiary deposits of Taben-Baluk, Western Kansu, Part II: Simplicidentata, Carnivora, Artiodactyla, Perissodactyla, and Primates. Palaeontologia Sinica C 8b, 1-259.

Bouzouggara A., Bartonb, N., Vanhaerend, M., d'Erricof, F., Collcutth, S., Highami, T., Hodgej, E., Parfittk, S., Rhodesm, E., Schwenningeri, J.L., Stringerk, C., Turnern, E., Wardo, S., Moutmirp, A. \& Stamboulip, A. 2007. 82,000-year-old shell beads from North Africa and implications for the origins of modern human behavior. Proceedings of the National Academy of Sciences of the United States of America 104, 9964-9969.

Bremer, K. 1994. Branch support and tree stability. Cladistics 10, 295-304.

Calendini, F. \& Martin, J. F. 2005. PaupUp: a free graphical frontend for Paup* Dos software, Version 1.0.3.1. J. F. Martin, Montpellier.

Cassoli, P. F. \& Durante, S. 1974. La fauna del Ti-n-Torha (Acacus, Libia). Origini 8, 159-161.

Coque, R. 1962. La Tunisie présaharienne: Étude géomorphologique. $\mathrm{PhD}$ thesis: Université de Paris, 467 pp.

Darlington, P. J. 1957. Zoogeography: the geographical distribution of animals. John Wiley and Sons, New York, 675 pp. 
Dashzeveg, D. \& Meng, J. 1998. New Eocene ctenodactyloid rodents from the eastern Gobi Desert of Mongolia and a phylogenetic analysis of ctenodactyloids based on dental features. American Museum Novitates 3246, 1-20.

De Bruijn, H. 1999. Superfamily Ctenodactyloidea. Pp. 263-266 in G. H. Rössner \& K. Heissig (eds) The Miocene land Mammals of Europe. Dr. Friedrich Pfeil, München.

De Bruijn, H., Hussain, S. T. \& Leinders, J. M. 1981. Fossil rodents from the Murree formation near Banda Daud Shah, Kohat, Pakistan. Proceedings of the Koninklijke Nederlandse Akademie van Wetenschappen, Series B 84, 71-99.

De Bruijn, H., Boon, E. \& Hussain, S. T. 1989. Evolutionary trends in Sayimys (Ctenodactylidae, Rodentia) from the Lower Manchar Formation (Sind, Pakistan). Proceedings of the Koninklijke Nederlandse Akademie van Wetenschappen, Series B 92, 191-214.

De Bruijn, H. \& Rümke, C. G. 1974. On a peculiar association from the Miocene of Oschiri (Sardinia). Proceedings of the Koninklijke Nederlandse Akademie van Wetenschappen, Series B 77, 45-79.

De Gregorio, A. 1887. Intorno a un deposito di roditori e di carnivori sulla vetta di Monte Pellegrino. Atti della Societa Toscana di Scienze Naturali Residente in Pisa 8, 3-39.

De Gregorio, A. 1925. Mammiferi quaternari di Sicilia: Microfauna di mammiferi e altri vertebrati (Myoxus, Lepus, Lagomis, Pellegrinia, Mustela, Crocidura, Lacerta e Testudo etc.). Annales de Géologie et de Paléontologie 43, 3-19.

Dehm, R., Jacobs, L., Wessels, W., De Bruijn, H. \& Hussain, S. T. 1982. Fossil Rodents from the type area of the Chinji Formation, Siwalik group, Pakistan. Proceedings of the Koninklijke Nederlandse Akademie van Wetenschappen, Series B 85, 259-263.

Dieterlen, F. 2005. Family Ctenodactylidae. Pp. 1536-1537 in D. E. Wilson \& M. A. Reeder (eds) Mammal Species of the World, a taxonomic and geographic Reference, Third edition. Johns Hopkins University Press, Baltimore.

Ellerman, J. R. \& Morrison-Scott, T. C. S. 1951. Checklist of Palaearctic and Indian Mammals, 1758 to 1946, First Edition. British Museum (Natural History), London, 810 pp.

Ellerman, J. R. \& Morrison-Scott, T. C. S. 1966. Checklist of Palaearctic and Indian Mammals, 1758 to 1946, Second Edition. British Museum (Natural History), London, 810 pp.

Fejfar, O. \& Horáček I. 2006. The Early Miocene mammalian assemblages in Jebel Zelten, Libya. Lynx 37, 95-105.

Felsenstein, J. 2005. PHYLIP (PHYLogeny Inference Package), Version 3.6. J. Felsenstein, Seattle.

Flynn, L. J. 2003. Small mammal indicators of forest paleoenvironment in the Siwalik deposits of the Potwar Plateau, Pakistan. Deinsea 10, 183-196. 
Flynn, L. J. \& Jacobs, L. L. 1990. Preliminary analysis of Miocene small mammals from Paşalar, Turkey. Journal of Human Evolution 19, 423-436.

Gautier, A. 1987. The archaeozoological sequence of the Acacus. Pp. 283-312 in B. E. Barich (ed.) Archaeology and Environment in the Libyan Sahara: The Excavations in the Tadrart Acacus, 1978-1983. British Archaeological Reports, Oxford.

Gautier, A. \& van Neer, W. 1982. Prehistoric fauna from Ti-n-Torha (Tadrart Acacus, Libya). Origini 11, 87-127.

George, W. 1979. The chromosomes of the hystricomorphous family Ctenodactylidae (Rodentia: ?Sciuromorpha) and their bearing on the relationships of the four living genera. Zoological Journal of the Linnean Society 65, 261-280.

George, W. 1982. Ctenodactylus (Ctenodactylidae, Rodentia): one species or two? Mammalia 46, $375-380$.

George, W. 1985. Cluster analysis and phylogenetics of five species of Ctenodactylidae (Rodentia). Mammalia 49, 53-63.

George, W. 2001. Gundis. Pp. 688-689 in D. Macdonald (ed.) The New Encyclopedia of Mammals. Oxford University Press, Oxford.

Geraads, D. 1985. Rongeurs et insectivores (Mammalia) du Pliocène final de Ahl A1 Oughlam (Casablanca, Maroc). Geobios 28, 99-115.

Geraads, D. 1998. Rongeurs du Mio-Pliocène de Lissasfa (Casablanca, Maroc). Geobios 31, 229245.

Geraads, D. 2002. Plio-Pleistocene mammalian biostratigraphy of Atlantic Morocco. Quaternaire 13, 43-53.

Gervais, M. P. 1853. Description ostéologique de l'Anomalurus et remarques sur la classification naturelle des rongeurs. Annales des Sciences Naturelles Zoologie et Biologie Animale 20, 238246.

Goldsmith, N. F., Tchernov, E., Ginsburg, L., Tassy, P. \& van Couvering, J. A. 1982. Ctenodactylid rodents in the Miocene Negev fauna of Israel. Nature 296, 645-647.

Goloboff, P. \& Farris, J. 2001. Methods for quick consensus estimation. Cladistics 17, 26-34.

Goloboff, P., Farris, J. \& Nixon K. C. 2008. TNT, a free program for phylogenetic analysis. Cladistics 24, 774-786.

Gray, J. E. 1830. Spicilegia zoologica: original figures and short systematic descriptions of new and unfigured animals. Partie 2. Treüttel, Würtz and Co, London.

Heissig, K. 1982. Kleinsäuger aus einer obermiozänen (Vallesium) Karstfüllung Ägyptens. Mitteilungen der Bayerischen Staatssammlung für Paläontologie und historische Geologie 22, 97-101. 
Hinton, M. A. C. 1933. Diagnoses of new genera and species of rodents from Indian Tertiary deposits. The Annals and Magazine of Natural History 12, 620-622.

Howe, K., Bateman, A. \& Durbin, R. 2002. QuickTree: building huge Neighbour-Joining trees of protein sequences. Bioinformatics 18, 1546-1547.

Hussain, S. T., Munthe, J., Shah, S. M. I., West, R. M. \& Lukacs, J. R. 1977. The Daud Khel Local fauna: a preliminary report on a Neogene vertebrate assemblage from the trans-indus Siwaliks, Pakistan. Milwaukee Public Museum, Contributions in Biology and Geology 16, 1-16.

Jaeger, J. J. 1971. Un cténodactylidé (Mammalia, Rodentia) nouveau, Irhoudia bohlini n.g. n. sp. du Pléistocène inférieur du Maroc, rapports avec les formes actuelles et fossiles. Notes et Memoires du Service Géologique du Maroc 31, 113-140.

Jaeger, J. J. 1974. Nouvelles faunes de rongeurs (Mammalia, Rodentia) du Miocène supérieur d'Afrique Nord-Occidentale. Annals of the Geological Survey of Egypt 4, 263-268.

Jaeger, J. J. 1975. Les Muridae (Mammalia, Rodentia) du Pliocène et du Pléistocène du Maghreb. Origine; evolution; données biogéographiques et paléoclimatiques. $\mathrm{PhD}$ thesis: Université Montpellier 2, 124 pp.

Jaeger, J. J. 1977. Les rongeurs du Miocène moyen et supérieur du Maghreb. Palaeovertebrata 8, $1-166$.

Joleaud, L. 1935. Gisements de Vertébrés quaternaires du Sahara. Bulletin de la Societé d'Histoire Naturelle de l'Afrique du nord 23 bis, 23-39.

Kaymakci, N. 2000. Tectono-stratigraphical evolution of the Çankiri Basin (Central Anatolia, Turkey). Geologica Ultraiectina 190, 1-247.

Kondopoulou, D., De Bonis, L., Koufos, G. D. \& Sen, S. 1993. Palaeomagnetic data and biostratigraphy of the middle Miocene vertebrate locality of Thymiana (Chios Island, Greece). Pp. 626-635 in Proceedings of the second congress of the Geophysical Society of Greece. Hellenic Geophysical Union, Athens.

Kordikova, E. G. \& De Bruijn, H. 2001. Early Miocene rodents from the Aktau Mountains (South-Eastern Kazakhstan). Senckenbergiana lethaea 81, 391-405.

Krijgsman, W., Duermeijer, C. E., Langereis, C. G., De Bruijn, H., Saraç, G. \& Andriessen, P. A. M. 1996. Magnetic polarity stratigraphy of Late Oligocene to Middle Miocene mammalbearing continental deposits in central Anatolia (Turkey). Newsletter on Stratigraphy 34, 13-29.

Kotsakis, T. 1986. Elementi di paleobiogeograpia dei mammiferi Terziari dell' italia. Hystrix 1, 2568.

Kotsakis, T. \& Palombo, M. R. 2009. Cenozoic mammalian palaeobiogeography of Sardinia. Pp. 47-50 in F. Fanti \& C. Spalletta (eds) International Conference on Vertebrate 
Palaeobiogeography and continental bridges across Tethys, Mesogea, and Mediterranean Sea Abstract book. Università di Bologna, Bologna.

Kumar, K. \& Kad, S. 2002. Early Miocene cricetid rodent (Mammalia) from the Murree Group of Kalakot, Rajauri District, Jammu and Kashmir, India. Current Science 82, 736-740.

Lataste, F. 1881. Sur un rongeur nouveau du Sahara algérien (Ctenodactylus mzabi n. sp.). Bulletin de la Société zoologique de France 6, 214-225.

Lataste, F. 1885. Sur le système dentaire du genre Ctenodactylus Gray. Le Naturaliste 3, 21-22.

Lataste, F. 1886. Novi subgeneris et novæ speciei rodentium, e genere Massoutiera diagnoses. Le Naturaliste 36, 287.

Lavocat, R. 1953. Sur diverses découvertes récentes de gisements de vertébrés africains et leurs conséquences géologiques. Compte rendu sommaire de la Société géologique de France 14, 284-286.

Lavocat, R. 1961. Le gisement de vertébrés miocènes de Beni Mellal (Maroc): étude systématique de la faune de mammifères. Notes et Mémoires du Service géologique du Maroc 155, 29-77.

Le Houérou, H.N. 1995. Bioclimatologie et Biogéographie des Steppes Arides du Nord de 1'Afrique. Diversité biologique, développement durable et désertisation. Options méditerranéennes B 10 CIHEAM, Montpellier, 396 pp.

Le Houérou, H.N. 1997. Climate, flora and fauna changes in the Sahara over the past 500 million years. Journal of Arid Environments 37, 619-647.

Lindsay, E. H., Flynn, L. J., Cheema, I. U., Barry, J. C., Downing, K., Rajpar, A. R. \& Raza, S. M. 2005. Will Downs and the Zinda Pir Dome. Palaeontologia Electronica 8, 19A,18 pp.

Lopatin, A. V. \& Zazhigin, V. S. 2000. [The history of the Dipodoidea (Rodentia, Mammalia) in the Miocene of Asia: 2. Zapodidae.]. Paleontologicheskii Zhurnal 2000, 86-91. [In Russian; also published in English in Paleontological Journal 34, 449-454].

López-Antoñanzas, R. \& Knoll, F. (in review). The oldest known Massoutiera (Rodentia: Ctenodactylinae). Mammalia.

López-Antoñanzas, R. \& Sen, S. 2003. Systematic revision of Mio-Pliocene Ctenodactylidae (Mammalia, Rodentia) from the Indian subcontinent. Eclogae Geologicae Helvetiae 96, 521529.

López-Antoñanzas, R. \& Sen, S. 2004. Ctenodactylids from the Lower and Middle Miocene of Saudi Arabia. Palaeontology 47, 1477-1494.

López-Antoñanzas, R., Sen, S. \& Saraç, G. 2004. A new large ctenodactylid species from the Lower Miocene of Turkey. Journal of Vertebrate Paleontology 24, 676-688. 
López-Antoñanzas, R., Sen, S. \& Koufos G. D. 2005. Presence of a ctenodactylid (Rodentia) in the Keramaria Formation (Middle Miocene) of Chios Island (Greece). Geobios 38, 113-126.

McKenna, M. C. \& Bell, S. K. 1997. Classification of Mammals above the Species level. Columbia University Press, New York, 631 pp.

Maddison, W. P. \& Maddison, D. R. 2009. Mesquite: a modular system for evolutionary analysis, Version 2.6. Mesquite Project, Vancouver.

Marra, A. C. 2005. Pleistocene mammals of Mediterranean islands. Quaternary International 129, $5-14$.

Martin, T. 1992. Schmelzmikrostruktur in den Inzisiven alt- und neuweltlicher hystricognather Nagetiere. Palceovertebrata Mémoire extraordinaire, 1-168.

Martin, T. 1993. Early rodent incisor enamel evolution: phylogenetic implications. Journal of Mammalian Evolution 1, 227-253.

Martin, T. 1995. Incisor enamel microstructure and phylogenetic interrelationships of Pedetidae and Ctenodactyloidea. Berliner geowissenschaftliche Abhandlungen, Reihe E 16, 693-707.

Mein, P. 2003. On Neogene rodents of Eurasia: distribution and migrations. Deinsea 10, 407-418.

Misonne, X. 1971. Order Rodentia. Pp. 1-39 in J. Meester \& H. W. Setzer (eds) The Mammals of Africa: an identification manual. Smithsonian Institution Press, Washington.

Munthe, J. 1980. Rodents of the Miocene Daud Khel Local Fauna, Mianwali District, Pakistan. Part 1. Sciuridae, Gliridae, Ctenodactylidae, and Rhyzomyidae. Milwaukee Public Museum, Contributions in Biology and Geology 34, 1-36.

Munthe, J. 1982. Small-Mammal Fossils from the Pliocene Sahabi Formation of Libya. Garyounis Scientific Bulletin, special issue 4, 33-39.

Munthe, J. 1987. Small-mammal fossils from the Pliocene Sahabi Formation of Libya. Pp. 135144 in N. T. Boaz, A. El-Arnauti, A. W. Gaziry, J. De Heinzelin \& D. D. Boaz (eds) Neogene Paleontology and Geology of Sahabi. Alan R. Liss, New York.

Nowak, R. M. 1999. Walker's Mammals of the World. The John Hopkins University Press, Baltimore, 2015 pp.

Peláez-Campomanes, P. \& Daams, R. 2002. Middle Miocene rodents from Paşalar, Anatolia, Turkey. Acta Palaeontologica Polonica 47, 125-132.

Peters, W. 1871. Contributions to the knowledge of Pectinator, a genus of rodent Mammalia from North-eastern Africa. Transactions of the Zoological Society of London 7, 397-409.

Prasad, K. N. 1970. The vertebrate fauna from the Siwalik beds of Haritalyangar, Himachal Pradesh, India. Palaeontologia Indica 39, 1-56.

Robinson, P. \& Black, C. C. 1973. A small Miocene faunule from near Testour, Beji Gouvernorat, Tunisia. Annales des Mines et de la Géologie 26, 445-449. 
Rothman, G. 1776. Reise nach Garean, im Gebiete von Tripoli, im Novemb. und Decemb. 1774: Ein Schreiben an den Ritter Wargentin in Stockholm. Pp. 326-342 in A. L. Schlözer (ed.) Neuer Briefwechsel historischen und politischen Inhalts. Heft V. Vandenhoek, Göttingen.

Savage, R. J. G. 1990. The African dimension in European Early Miocene mammal faunas. Pp. 587-599 in E. H. Lindsay, V. Falhbusch \& P. Mein (eds) European Neogene Mammal Chronology. Plenum Press, New York.

Schmidt-Kittler, N., Vianey-Liaud, M. \& Marivaux, L. 2007. The Ctenodactylidae (Rodentia, Mammalia). Annalen des Naturhistorischen Museums in Wien 108A, 173-215.

Sen, S. \& Thomas, H. 1979. Découverte de rongeurs dans le Miocène moyen de la Formation Hofuf (Province du Hasa, Arabie Saoudite). Compte rendu sommaire de la Société géologique de France 21, 34-37.

Shevyreva, N. S. 1994. [A new Neogene Ctenodactyloidea (Rodentia, Mammalia) from the Zaysan Basin (Eastern Kazakhstan).]. Paleontologicheskii Zhurnal 1994, 126-131. [In Russian; also published in English in Paleontological Journal 28, 160-167].

Sondaar, P. Y. \& Van der Geer, A. A. E. 2005. Evolution and Extinction of Plio-Pleistocene Island Ungulates. Quaternaire, hors série 2, 241-256.

Stöck, M., Sicilia, A., Belfiore, N. M., Buckley, D., Lo Brutto, S., Lo Valvo, M. \& Arculeo, M. 2008. Post-Messinian evolutionary relationships across the Sicilian channel: Mitochondrial and nuclear markers link a new green toad from Sicily to African relatives. Evolutionary Biology $\mathbf{8}$, $1-19$.

Sümengen, M., Ünay, E., Sarac, G., De Bruijn, H., Terlemez, I. \& Gürbüz, M. 1990. New Neogene rodent assemblages from Anatolia (Turkey). Pp. 61-72 in E. H. Lindsay, V. Falhbusch \& P. Mein (eds) European Neogene Mammal Chronology. Plenum Press, New York.

Swofford, D. L. 2002. PAUP*: Phylogenetic Analysis Using Parsimony (*and other methods), Version 4.0b10. Sinauer Associates, Sunderland.

Tchernov, E., Ginsburg, L., Tassy, P. \& Goldsmith, N. F. 1987. Miocene mammals of the Negev (Israel). Journal of Vertebrate Paleontology 7, 284-310.

Thaler, L. 1972. Les rongeurs (Rodentia et Lagomorpha) du Monte Pellegrino et la question des anciens isthmes de la Sicile. Comptes rendus de l'Académie des Sciences, Série D 274, 188-190.

Thomas, O. 1902. On the mammals collected during the Whitaker Expedition to Tripoli. Proceedings of the Zoological Society of London 2, 2-13.

Thomas, O. 1919. The types of the mammals described by M. Fernand Lataste. The Annals and Magazine of Natural History 4, 350-354.

Thomas, O. 1920. A note on the type-locality and geographical races of the Gundi (Ctenodactylus gundi Rothm.). Novitates Zoologicae 27, 506-507.Ünay, E., Atabey, E. \& Sarac, G. 2001. 
Small mammals and foraminifera from the Anatolian (Central Taurus) early Miocene. Annals of Carnegie Museum 70, 247-256.

Vasileiadou, K. \& Koufos, G. D. 2005. The micromammals from the Early/Middle Miocene locality of Antonios, Chalkidiki, Greece. Annales de Paléontologie 91, 197-225.

Vasishat, R. N. 1978. First record of maxillary dentition of Sayimys perplexus (Ctenodactylidae) from the Indian Siwaliks. Current Science 47, 859-860.

Vasishat, R. N. 1985. Antecedents of early Man in northwestern India: paleontological and paleoecological Evidences. Inter-India Publications, New Delhi.

Vaufrey, R. 1955. Préhistoire de l'Afrique Volume 1 Maghreb. Masson, Paris, pp. 458.Villa, P. 2001. Early Italy and the colonization of Western Europe. Quaternary International 75, 113 130.

Wanas, H. A., Pickford, M., Mein, P., Soliman, H. \& Segalen, L. 2009. Late Miocene karst system at Sheikh Abdallah, between Bahariya and Farafra, Western Desert, Egypt: Implications for palaeoclimate and geomorphology. Geologica Acta 7, 475-487.

Wang, B. Y. 1994. The Ctenodactyloidea of Asia. National Science Museum Monographs 8, 3547.

Wang, B. Y. 1997. The mid-Tertiary Ctenodactylidae (Rodentia, Mammalia) of eastern and central Asia. Bulletin of the American Museum of Natural History 234, 1-88.

Wang, B. Y., Qiu, Z. X., Wang, X. M., Xie, G., Xie, J. Y., Downs, W., Qiu, Z. D. \& Deng., T. 2003. [Cenozoic stratigraphy in Danghe area, Gansu Province, and uplift of Tibetan plateau.]. Vertebrata Palasiatica 41, 66-75. [In Chinese with English abridged version].

Wang, X. M., Wang, B. Y. \& Qiu, Z. X. 2008. Early explorations of Tabenbuluk region (western Gansu province) by Birger Bohlin-reconciling classic vertebrate fossil localities with modern stratigraphy. Vertebrata Palasiatica 46, 1-19.

Wessels, W., De Bruijn, H., Hussain, S. T. \& Leinders, J. 1982. Fossil rodents from the Chinji Formation, Banda Daud Shah, Kohat, Pakistan. Proceedings of the Koninklijke Nederlandse Akademie van Wetenschappen, Series B 85, 337-364.

Wessels, W., Fejfar, O., Peláez-Campomanes, P. \& De Bruijn, H. 2003. Miocene small mammals from Jebel Zelten, Libya. Coloquios de Paleontología volumen extraordinario, 699715.

Wessels, W., Fejfar, O., Peláez-Campomanes, P., Van Der Meulen, A., De Bruijn, H. \& ElArnauti, A. 2008. The age of the small mammal faunas from Jabal Zaltan, Libya. Garyounis Scientific Bulletin, special issue 5, 129-138. 
Wible, J. R., Wang, Y., Li, C. \& Dawson, M. 2005. Cranial anatomy and relationships of a new ctenodactyloid (Mammalia, Rodentia) from the Early Eocene of Hubei province, China. Annals of the Carnegie Museum 74, 91-150.

Wood, A. E. 1937. Fossil rodents from the Siwalik beds of India. American Journal of Science 34, 64-76.

Wood, A. E. 1977. The evolution of the rodent family Ctenodactylidae. Journal of the Palaeontological Society of India 20, 120-137.

Wood, A. E. \& Goldsmith, N. F. 1998. Early Miocene rodents and lagomorphs from Israel. Journal of Vertebrate Paleontology 18 (suppl. to 3), 87A-88A.

Yarrell, W. E. 1830. On the Anatomy, and c. of the Ctenodactylus Massonii, Gray (Mus Gundi Rothm.). Proceedings of the Committee of Science and Correspondence of the Zoological Society of London 1, 48-50. 


\section{Figure captions}

Figure 1. Distribution of the extant Ctenodactylinae (after IUCN data) and fossil localities. 1, Ulaan Tolgoi (Mongolia); 2, Tabenbuluk (China); 3, Batpaksunde (Kazakhstan); 4, Aktau Mountains

(Kazakhstan); 5, Badaun (India); 6, Haritalyangar (India); 7, Ramnagar (India); 8, Chinji (Pakistan); 9, Banda Daud Shah (Pakistan); 10, Zinda Pir Dome (Pakistan); 11, Sind (Pakistan); 12, Hórlak (Turkey); 13, Keseköy (Turkey); 14, Hijarcik (Turkey); 15, Çatalarkaç (Turkey); 16, Mut (Turkey); 17, Paşalar (Turkey); 18, Thymiana (Greece); 19, Antonios (Greece); 20, Monte Pellegrino (Italy); 21, Oschiri (Italy); 22, As-Sarrar (Saudi Arabia); 23, Al-Jadidah (Saudi Arabia); 24, Tayma (Saudi Arabia); 25, Negev (Israel); 26, Sheikh Abdallah (Egypt); 27, As Sahabi (Libya); 28, Jebel Zelten (Libya); 29, Testour (Tunisia); 30, Amama (Algeria); 31, Oued Zra (Morocco); 32, Ahl al Oughlam (Morocco); 33, Lissasfa (Casablanca, Morocco); 34, Jebel Rhassoul (Morocco); 35, Azdal (Morocco); 36, Beni-Mellal (Morocco); 37, Jbel Irhoud (Morocco); 38, Pataniak (Morocco).

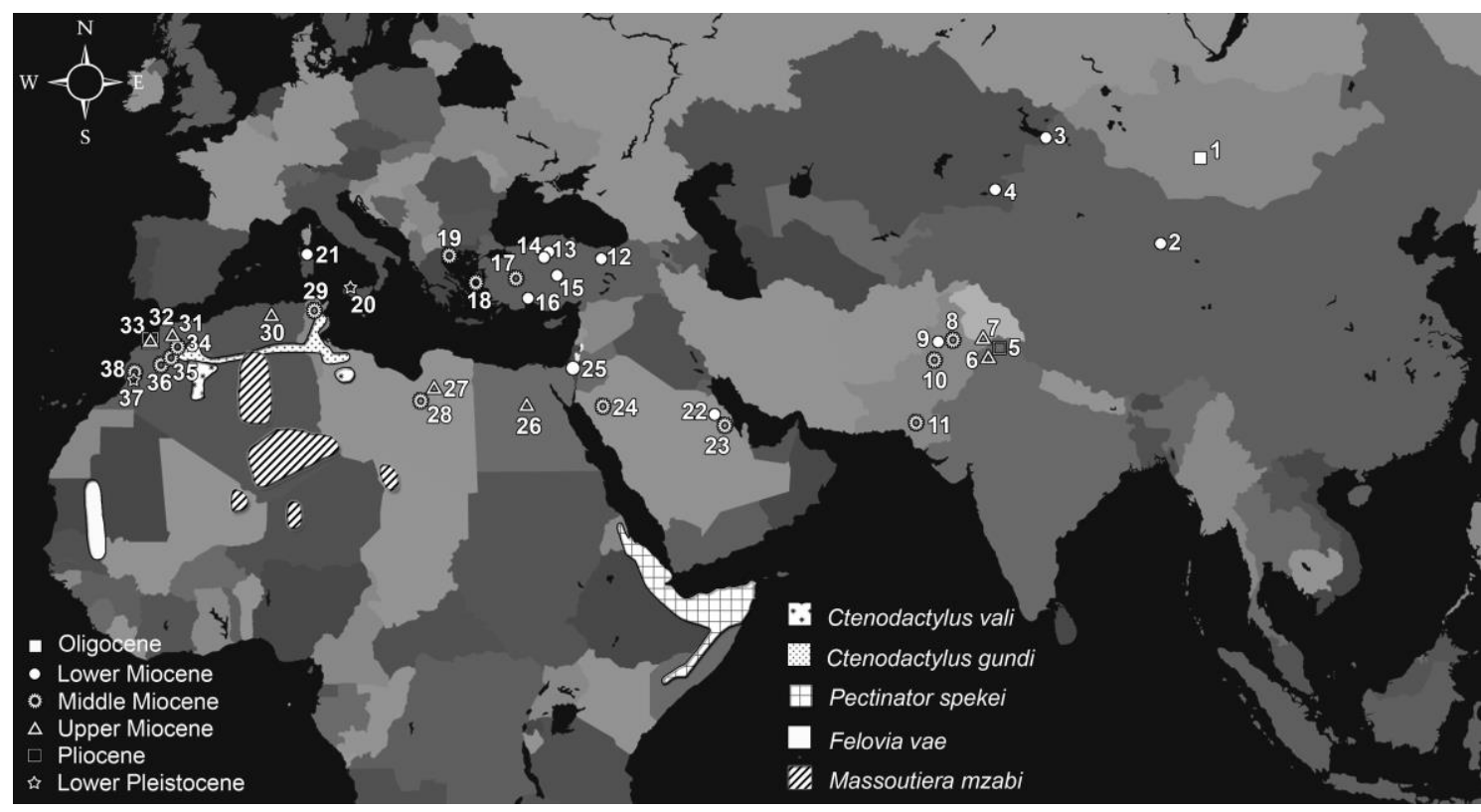

Figure 2. Ctenodactyline dental terminology used in this paper. A, left maxilla with P4-M2; B, right D4; C, right p4; D, right dp4; $\mathbf{E}$, right $\mathrm{m1-2}$. Scale bar equals $1 \mathrm{~mm}$. 


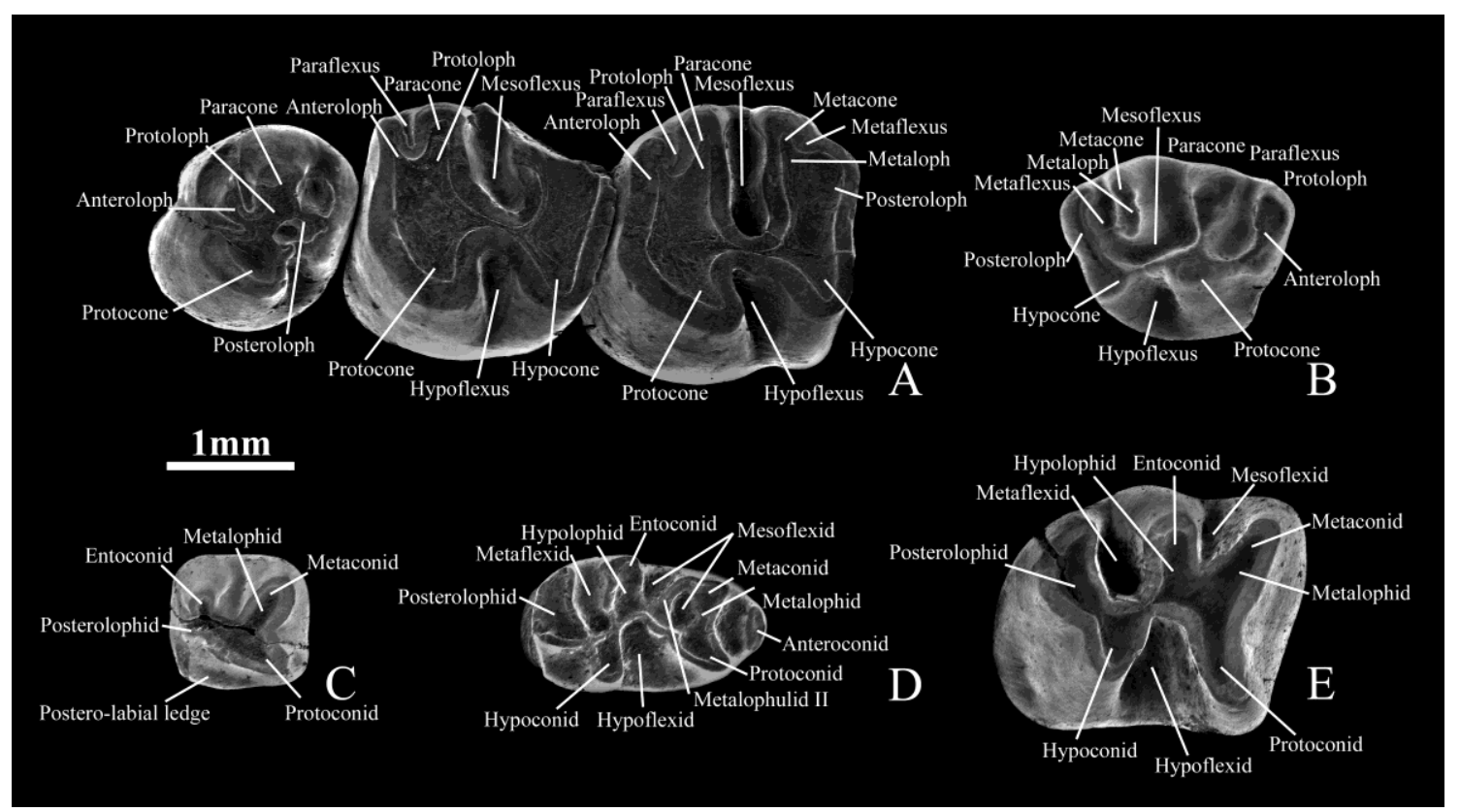

Figure 3. Diagnosis of Mus gundi provided by G. Rothman (1776).

M vs Gundi, caụda abbreuiata, pedibus omnibus te. tradaftylis. Corpus totum teftaceo-rufefcens. Auricuse lae truncatae, apertura larga, orata. Dentes primores excauati, fuperiores truncati, inferiores fubulati. Digiti omnes unguiculati. Plantae talis infirtentes, Magnitudo cuniculi minoris.

Figure 4. Cheek teeth of Massoutiera mzabi and Felovia vae. A, upper cheek teeth of M. mzabi (specimen C.G.1912 N³22) with P4-M3; B, upper cheek teeth of F. vae (specimen C.G.1994 $\mathrm{N}^{\circ}$ 613) with P4-M3; C, lower cheek teeth of M. mzabi (specimen C.G.1912 N³22) with p4-m3; D, lower cheek teeth of $F$. vae (specimen C.G.1994 Nº13) with m1-m3 and socket for the p4. Except for the upper cheek teeth of $F$. vae, all specimens are figured with anterior to left. Scale bar equals $2 \mathrm{~mm}$.

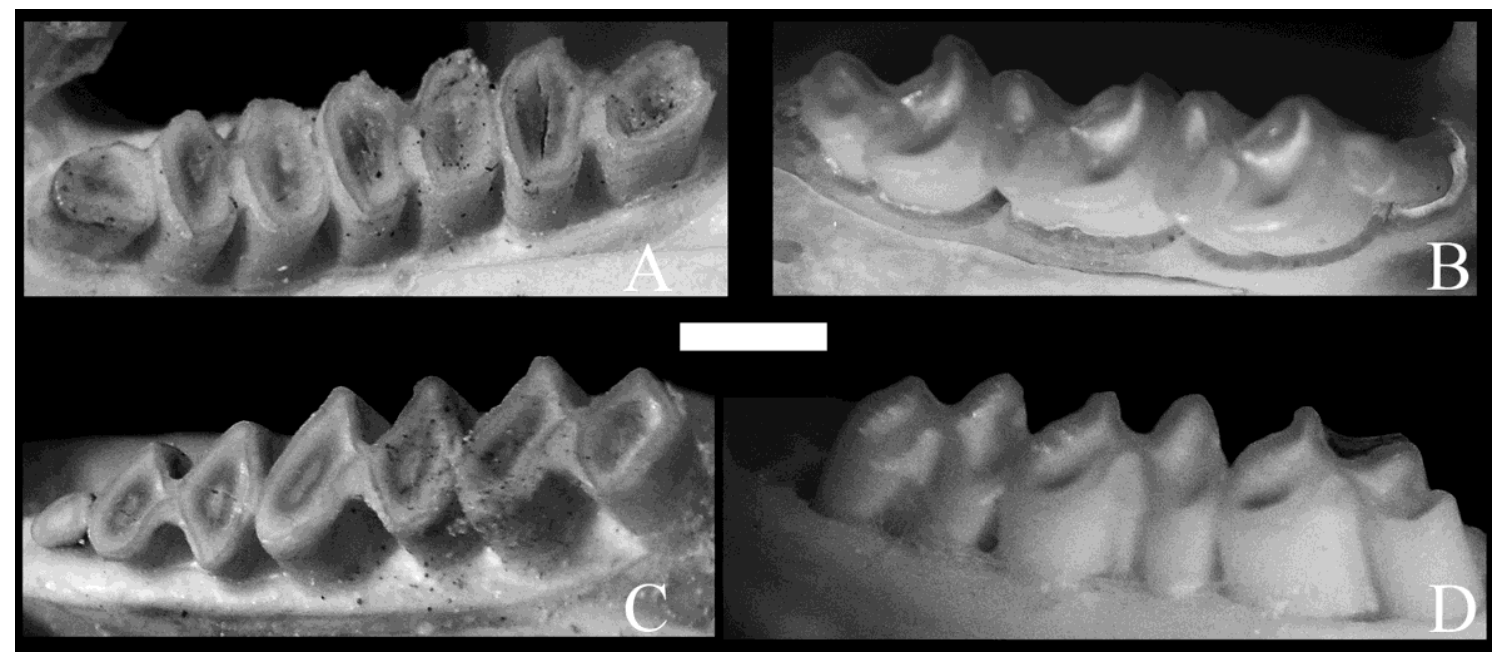


Figure 5. Cheek teeth of Pectinator spekei (specimen M.B. 71169). A, mandible with dp4-m3; B, maxilla with P4-M3. All specimens are figured with anterior to left. Scale bar equals $2 \mathrm{~mm}$.

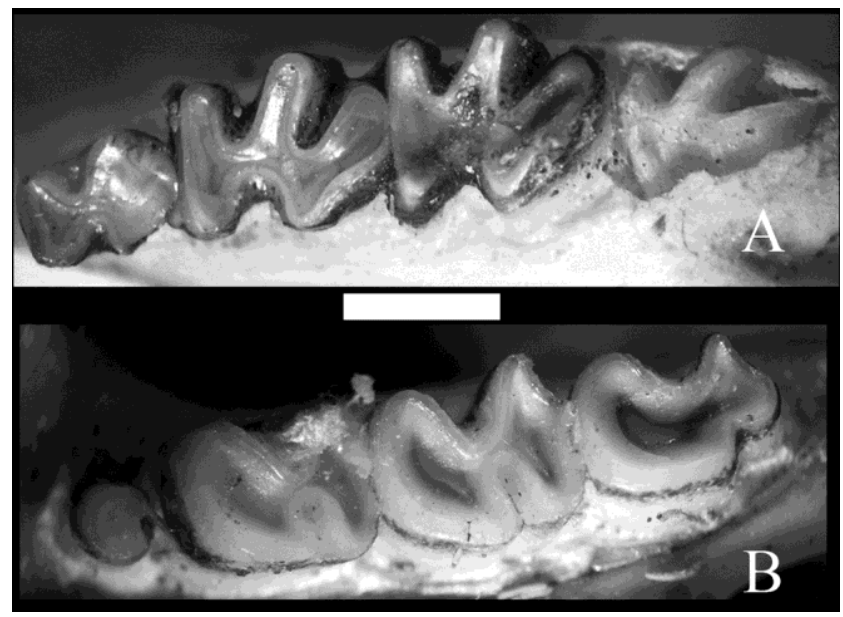

Figure 6. Previous works. A, unrooted phenogram obtained from the dissimilarity indices given by George (1979); B, majority rule consensus tree generated by the cladistic analysis of all species of Sayimys, Prosayimys, and Metasayimys performed by López-Antoñanzas et al., (2004); C, most parsimonious tree found by George (1985) including the five extant species of Ctenodactylinae; D, clade of the strict consensus tree generated by the the cladistic analysis carried out by Wible (2005) showing the relationships of three ctenodactylines. 

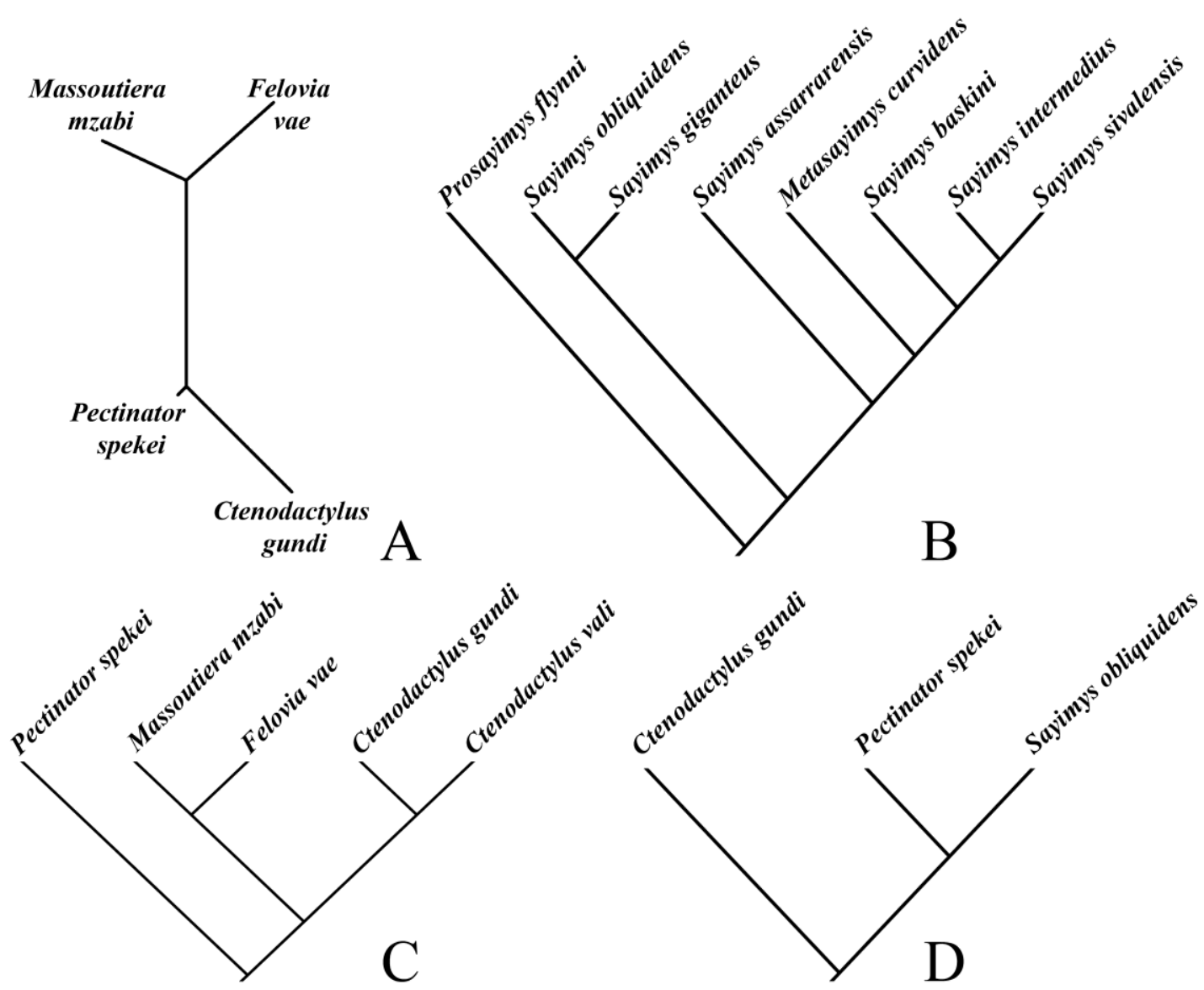

Figure 7. Consensus trees generated by the cladistic analysis of the Ctenodactylinae performed in this paper (matrix in Appendix 3). A, strict and semi-strict consensus trees, Bremer and Relative Bremer Indices are showed at the appropriate nodes; B, majority-rule consensus tree, nodes are designed by numbers 49 to 27 . The trees have a length of 127 steps, a consistency index (CI) of 0.4567 and a retention index $(\mathrm{RI})$ of 0.7305 . 

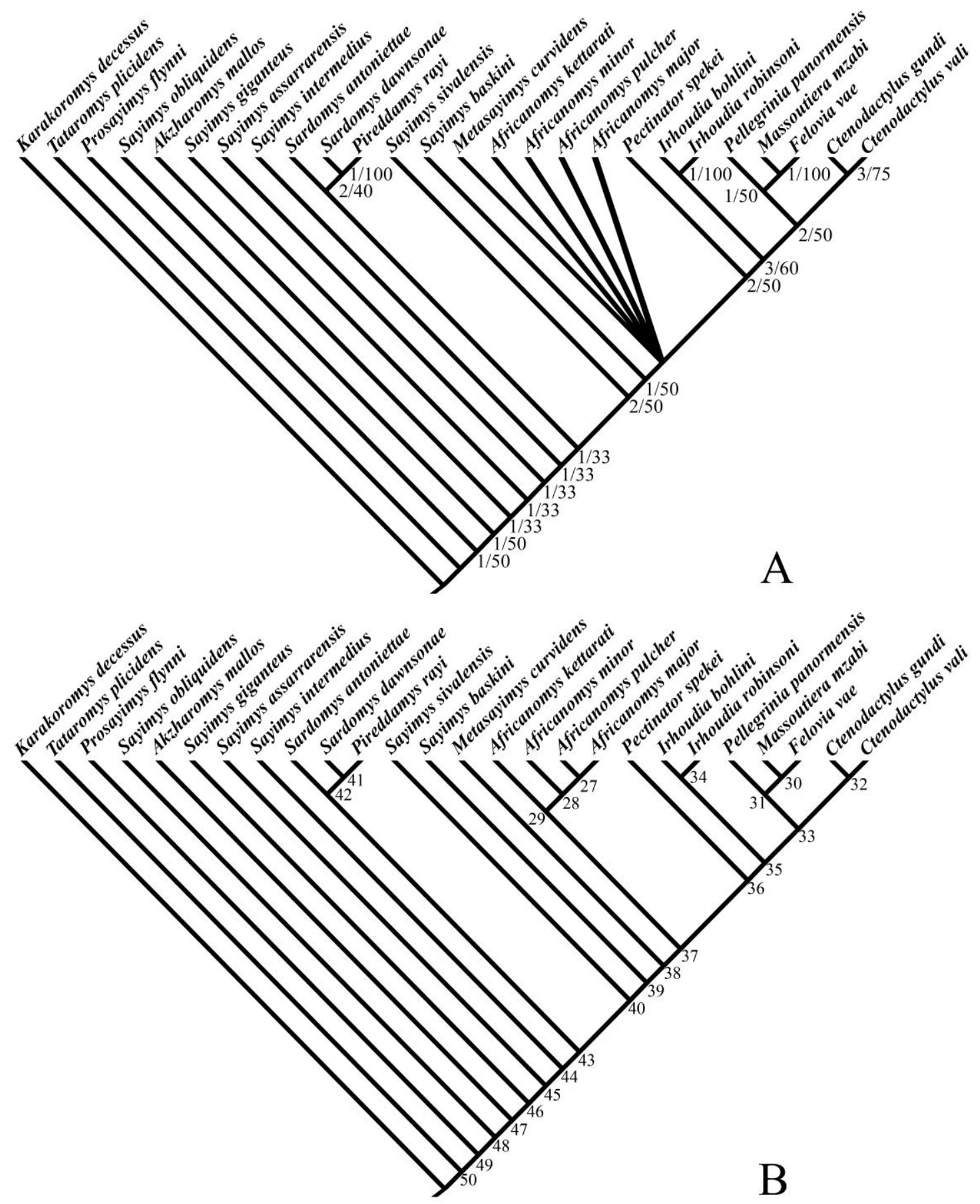


\section{Table caption}

Table 1. Transformations supporting the topology of the $50 \%$ majority rule consensus tree under acctran and deltran optimisations. Bold indicates exclusive synapomorphies at internal nodes and autapomorphies in terminal ingroup taxa. Italics indicate synapomorphies that change with the optimisation. 


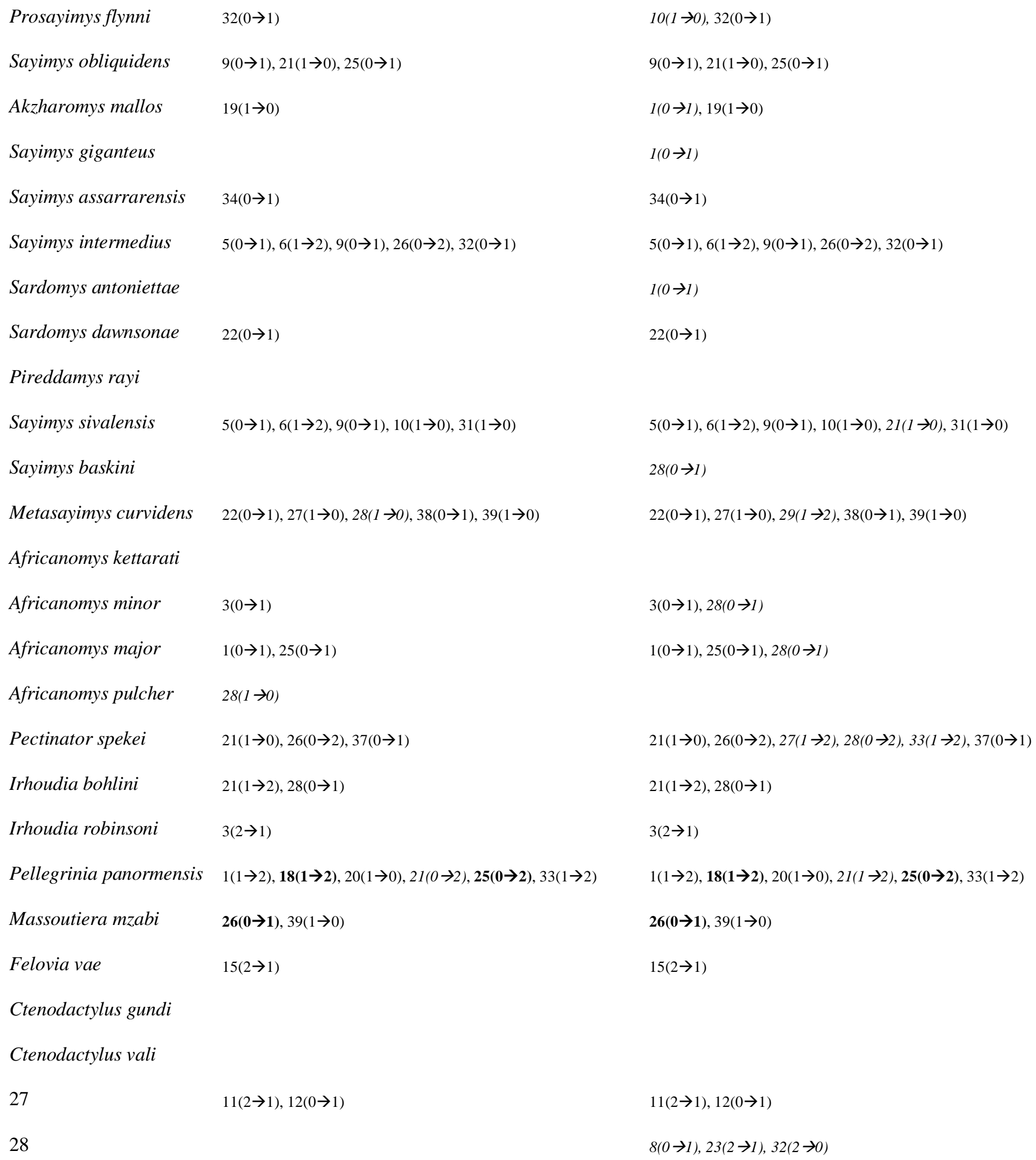

Ctenodactylus gundi

Ctenodactylus vali 


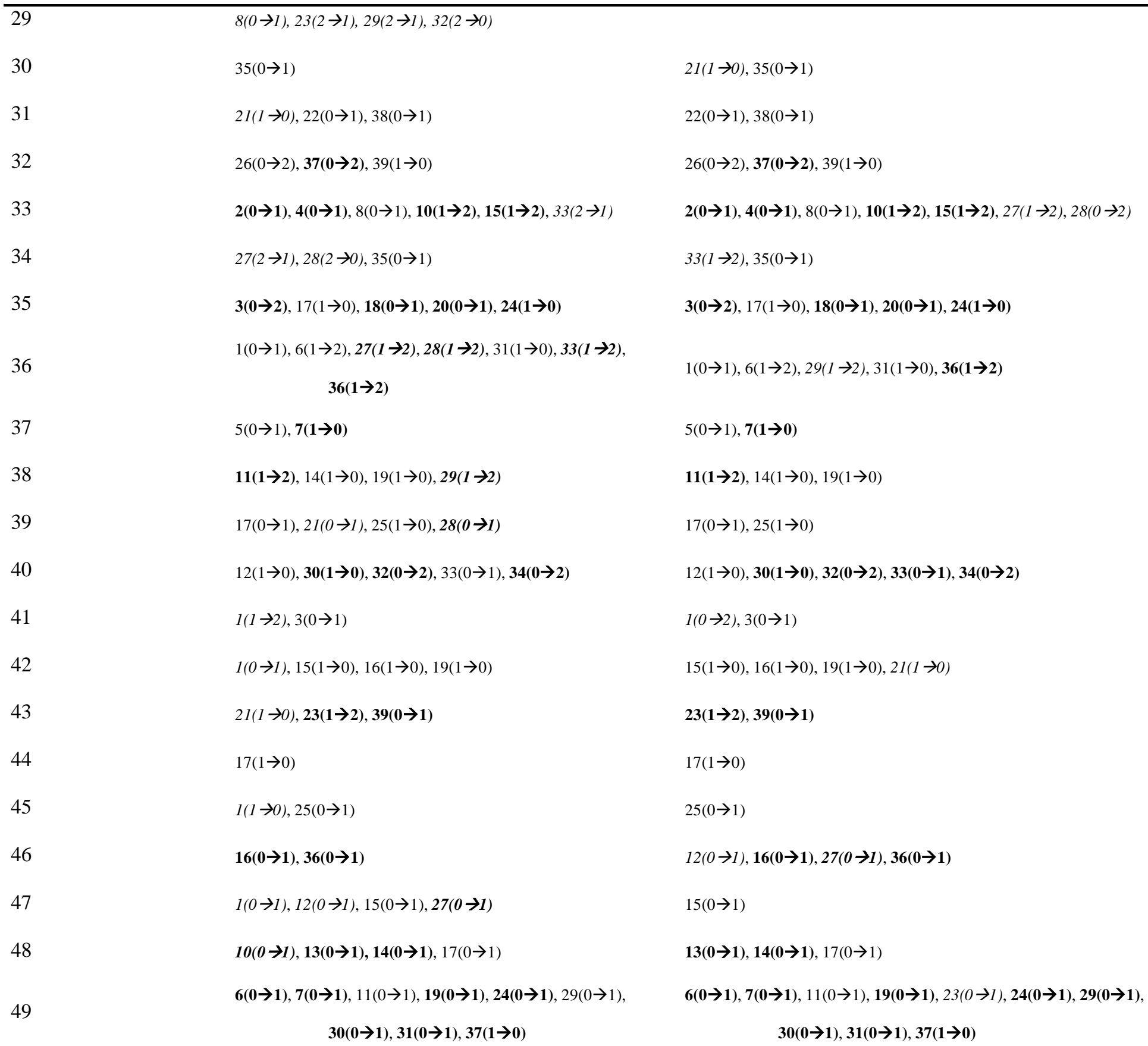

Appendix 1 Distance matrix constructed on the basis of George's (1979) dissimilarity indices.

Appendix 2 Characters used in the phylogenetic analysis. 19 characters are binary whereas 20 are multistate, polarity of character determined by outgroup comparison with Karakoromys decessus and Tataromys plicidens. 
Appendix 3 Matrix of character codings used in the analysis of relationships of all species of Ctenodactylinae. Characters are listed in Appendix 2. Character codings: 0, 1 and 2, conditions of character; -, uncodable character; ?, character state uncertain.

\section{Appendix 1}

\begin{tabular}{|l|l|l|l|l|}
\hline \multicolumn{1}{|c|}{4} & & & & \\
\hline Pectinator & 000 & 100 & 100 & 050 \\
\hline Felovia & 100 & 000 & 065 & 150 \\
\hline Massoutiera & 100 & 065 & 000 & 135 \\
\hline Ctenodactylus & 050 & 150 & 135 & 000 \\
\hline
\end{tabular}

\section{Appendix 2}

1. Size: (0) small; (1) intermediate; (2) large

2. (0) rooted cheek teeth; (1) ever-growing cheek teeth

3. (0) brachyodont; (1) semi-hypsodont; (2) Hypsodont

\section{dp4}

4. (0) not reduced; (1) reduced

5. Metalophulid II: (0) present; (1) absent

6. Metaconid: (0) connected to the metalophulid II; (1) connected to the metalophulid II and to the protoconid; (2) connected to the protoconid

7. Anteroconid: (0) absent; (1) present 
8. Metaconid: (0) anteriorly situated; (1) extremely anteriorly situated (on the anterior edge of the tooth)

9. Posterolabial cingulum: (0) absent or weak; (1) strong

10. Hypolophid: (0) oblique; (1) transverse; (2) absent (at early stages of wear)

\section{p4}

11. (0) not reduced; (1) reduced; (2) very reduced

12. Posterolophid: (0) absent or weak; (1) present

13. Shape in occlusal view: (0) U-shaped pattern; (1) Y-shaped pattern

14. Postero-labial ledge: (0) absent; (1) present

\section{m1-m2}

15. Lobes: (0) four; (1) three; (2) two

16. Metalophulid II: (0) present; (1) absent

17. Mesoflexid: (0) equal or longer than the metaflexid; (1) shorter than the metaflexid

18. Metaflexid: long (0); (1) short; (2) absent

19. Postero-labial ledge: (0) absent; (1) moderate; (2) strong

20. Hypertrophy of the protoconid: (0) no; (1) yes

21. Hypolophid: (0) oblique; (1) transverse or slightly oblique (2) absent

22. Cement (on the m2-m3): (0) absent; (1) present

23. (0) $\mathrm{m} 2$ longer than $\mathrm{m} 3$; (1) $\mathrm{m} 2$ equal in length with $\mathrm{m} 1$; (2) $\mathrm{m} 2$ shorter than $\mathrm{m} 3$

24. End of the hypoflexid: (0) anterior to the hypolophid; (1) in front of the hypolophid

25. Posterolophid: (0) not bended towards the entoconid; (1) bended towards the entoconid; (2) absent 
26. Longitudinal groove: (0) present; (1) weak; (2) absent

\section{DP4}

27. Metaflexus: (0) long; (1) short; (2) absent at early stages of wear

28. Paraflexus: (0) long; (1) short; (2) absent at early stages of wear

\section{P4}

29. (0) not reduced; (1) reduced; (2) very reduced

30. Anteroloph: (0) absent or weak; (1) well developed

31. Lingual re-entrant fold: (0) absent; (1) present

32. Posteroloph: (0) longer than anteroloph; (1) shorter than anteroloph; (2) very weak or absent

\section{M1-M2}

33. Lobes: (0) four; (1) three; (2) two

34. Paraflexus: (0) long; (1) short; (2) absent

35. Hypertrophy of the protocone: (0) no; (1) yes

36. Metaflexus: (0) long; (1) short; (2) absent

37. Hypoflexus: (0) deep; (1) shallow; (2) absent

38. Cement: (0) absent; (1) present

\section{M3}

39. Posterior lobe: (0) not reduced; (1) reduced 


\section{Appendix 3}

\begin{tabular}{|c|c|c|c|c|c|c|c|c|c|c|c|c|c|c|c|c|c|c|c|c|c|c|c|c|c|c|c|c|c|c|c|c|c|c|c|c|c|c|c|}
\hline & \begin{tabular}{|l|}
1 \\
\end{tabular} & 2 & 3 & 4 & 5 & 6 & 7 & 8 & 9 & 10 & 11 & 12 & 13 & 14 & 15 & 16 & \begin{tabular}{|l|l}
17 \\
\end{tabular} & 18 & \begin{tabular}{|l|l}
3 & 19
\end{tabular} & 20 & 21 & 22 & 23 & \begin{tabular}{|l|}
24 \\
\end{tabular} & 25 & 26 & 27 & 28 & \begin{tabular}{|l|l|}
329 \\
\end{tabular} & \begin{tabular}{|l|l}
$\mathbf{3 0}$
\end{tabular} & 31 & 32 & $\mathbf{3 3}$ & 34 & 35 & 36 & \begin{tabular}{|l}
37 \\
\end{tabular} & 38 & 39 \\
\hline Karakoromys & 0 & 0 & 0 & 0 & 0 & 0 & 0 & 1 & 0 & 1 & 0 & 0 & 0 & 0 & 0 & 0 & 0 & 0 & 0 & 0 & 1 & 0 & $0 \& 1 \& 2$ & \begin{tabular}{|l|}
0 \\
\end{tabular} & 0 & 0 & 0 & 0 & 0 & 0 & 0 & 0 & 0 & 0 & \begin{tabular}{|l}
0 \\
\end{tabular} & 0 & 1 & 0 & 1 \\
\hline \begin{tabular}{|l} 
Tataromys \\
\end{tabular} & 2 & 0 & 0 & 0 & 0 & 0 & 0 & 0 & 0 & 0 & 0 & 0 & 0 & 0 & 0 & 0 & 0 & 0 & 0 & 0 & 0 & 0 & 0 & 0 & 0 & 0 & 0 & 0 & 0 & 0 & 0 & 0 & 0 & 0 & 0 & 0 & 1 & 0 & 0 \\
\hline Prosayimys flynni & 0 & 0 & 0 & 0 & 0 & 1 & 1 & 0 & ? & 0 & 1 & 0 & 0 & 0 & 0 & 0 & 0 & 0 & 1 & 0 & 1 & 0 & 1 & 1 & 0 & $?$ & 0 & 0 & 1 & 1 & 1 & 1 & 0 & 0 & 0 & 0 & 0 & 0 & 0 \\
\hline Sardomys antoniettae & 1 & 0 & 0 & ? & ? & ? & ? & ? & ? & $?$ & 1 & 1 & 1 & 1 & 0 & 0 & 0 & 0 & 0 & 0 & 0 & $?$ & ? & 1 & 1 & 0 & $?$ & $?$ & 1 & 1 & 1 & $?$ & $?$ & $?$ & ? & ? & $?$ & $?$ & $?$ \\
\hline Sardomys dawsonae & 2 & 0 & 1 & 0 & 0 & 1 & 1 & 0 & 0 & 1 & 1 & 1 & 1 & 1 & 0 & 0 & 0 & 0 & 0 & 0 & 0 & 1 & 2 & 1 & 1 & 0 & $?$ & $?$ & ? & $?$ & $?$ & $?$ & 0 & 0 & 0 & 1 & 0 & 0 & 1 \\
\hline Pireddamys rayi & 2 & 0 & 1 & ? & ? & ? & ? & ? & ? & $?$ & ? & $?$ & $?$ & $?$ & 0 & 0 & 0 & 0 & 0 & 0 & 0 & 0 & 2 & 1 & 1 & 0 & ? & $?$ & 1 & 1 & 1 & 0 & 0 & 0 & 0 & 1 & 0 & 0 & ? \\
\hline Sayimys obliquidens & 0 & 0 & 0 & 0 & 0 & 1 & 1 & 0 & 1 & 1 & 1 & 0 & 1 & 1 & 0 & 0 & 1 & 0 & 1 & 0 & 0 & 0 & 1 & 1 & 1 & 0 & 0 & 0 & 1 & 1 & 1 & 0 & 0 & 0 & 0 & 0 & 0 & 0 & 0 \\
\hline Sayimys giganteus & 1 & 0 & 0 & 0 & 0 & 1 & 1 & 0 & 0 & 1 & 1 & 1 & 1 & 1 & 1 & 1 & 1 & 0 & 1 & 0 & 1 & 0 & 1 & 1 & 0 & $?$ & 1 & 0 & 1 & 1 & 1 & 0 & 0 & 0 & 0 & 1 & 0 & 0 & 0 \\
\hline Sayimys baskini & 0 & 0 & 0 & 0 & 0 & 1 & 1 & 0 & 0 & 1 & 1 & 0 & 1 & 1 & 1 & 1 & 1 & 0 & 1 & 0 & $0 \& 1$ & 0 & 2 & 1 & 0 & $?$ & 1 & 1 & 1 & 0 & 1 & - & 1 & 2 & 0 & 1 & 0 & 0 & 1 \\
\hline Akzharomys mallos & 1 & 0 & 0 & ? & ? & ? & ? & ? & ? & $?$ & ? & $?$ & $?$ & ? & 1 & 0 & 1 & 0 & 0 & 0 & 1 & 0 & ? & 1 & 0 & $?$ & ? & ? & ? & $?$ & $?$ & ? & 0 & 0 & 0 & 0 & 0 & 0 & ? \\
\hline Sayimys intermedius & 0 & 0 & 0 & 0 & 1 & 2 & 1 & 0 & 1 & 1 & 1 & 1 & 1 & 1 & 1 & 1 & 0 & 0 & 1 & 0 & 1 & 0 & 1 & 1 & 1 & 2 & 1 & 0 & 1 & 1 & 1 & 1 & 0 & 0 & 0 & 1 & 0 & 0 & 0 \\
\hline Sayimys assarrarensis & 0 & 0 & 0 & 0 & 0 & 1 & 1 & 0 & 0 & 1 & 1 & 1 & 1 & 1 & 1 & 1 & 1 & 0 & 1 & 0 & 1 & 0 & ? & 1 & 1 & $?$ & 1 & 0 & 1 & 1 & 1 & 0 & 0 & 1 & 0 & 1 & 0 & 0 & ? \\
\hline Sayimys sivalensis & 0 & 0 & 0 & 0 & 1 & 2 & 1 & 0 & 1 & 0 & 1 & 0 & 1 & 1 & 1 & 1 & 0 & 0 & 1 & 0 & 0 & 0 & 2 & 1 & 1 & $?$ & 1 & 0 & 1 & 0 & 0 & 2 & 1 & $1 \& 2$ & 0 & 1 & 0 & 0 & 1 \\
\hline Metasayimys curvidens & 0 & 0 & 0 & 0 & 0 & 1 & 1 & 0 & 0 & 1 & 2 & 0 & 1 & 0 & 1 & 1 & 1 & 0 & 0 & 0 & 1 & 1 & 2 & 1 & \begin{tabular}{|l|}
0 \\
\end{tabular} & 0 & 0 & 0 & 2 & 0 & 1 & 2 & 1 & $1 \& 2$ & \begin{tabular}{|l|}
0 \\
\end{tabular} & 1 & 0 & 1 & 0 \\
\hline Africanomys pulcher & 0 & 0 & 0 & 0 & 1 & 1 & 0 & 1 & 0 & 1 & 1 & 1 & 1 & 0 & 1 & 1 & 1 & 0 & 0 & 0 & 1 & 0 & 1 & 1 & 0 & $?$ & 1 & 0 & $\overline{1}$ & 0 & 1 & 0 & 1 & $1 \& 2$ & 0 & 1 & 0 & 0 & 1 \\
\hline Africanomys major & 1 & 0 & 0 & 0 & 1 & 1 & 0 & 1 & 0 & 1 & 1 & 1 & 1 & 0 & 1 & 1 & 1 & 0 & 0 & 0 & 1 & 0 & 1 & 1 & 1 & $?$ & 1 & 1 & 1 & 0 & 1 & 0 & 1 & $1 \& 2$ & 0 & 1 & 0 & 0 & 1 \\
\hline Africanomys minor & 0 & 0 & 1 & 0 & 1 & 1 & 0 & 1 & 0 & 1 & 2 & 0 & - & 0 & 1 & 1 & 1 & 0 & 0 & 0 & 1 & 0 & 1 & 1 & 0 & $?$ & 1 & 1 & 1 & 0 & 1 & 0 & 1 & $1 \& 2$ & 0 & 1 & 0 & 0 & 1 \\
\hline
\end{tabular}




\begin{tabular}{|l|c|c|c|c|c|c|c|c|c|c|c|c|c|c|c|c|c|c|c|c|c|c|c|c|c|c|c|c|c|c|c|c|c|c|c|c|c|c|c|c|c|}
\hline & $\mathbf{1}$ & $\mathbf{2}$ & $\mathbf{3}$ & $\mathbf{4}$ & $\mathbf{5}$ & $\mathbf{6}$ & $\mathbf{7}$ & $\mathbf{8}$ & $\mathbf{9}$ & $\mathbf{1 0}$ & $\mathbf{1 1}$ & $\mathbf{1 2}$ & $\mathbf{1 3}$ & $\mathbf{1 4}$ & $\mathbf{1 5}$ & $\mathbf{1 6}$ & $\mathbf{1 7}$ & $\mathbf{1 8}$ & $\mathbf{1 9}$ & $\mathbf{2 0}$ & $\mathbf{2 1}$ & $\mathbf{2 2}$ & $\mathbf{2 3}$ & $\mathbf{2 4}$ & $\mathbf{2 5}$ & $\mathbf{2 6}$ & $\mathbf{2 7}$ & $\mathbf{2 8}$ & $\mathbf{2 9}$ & $\mathbf{3 0}$ & $\mathbf{3 1}$ & $\mathbf{3 2}$ & $\mathbf{3 3}$ & $\mathbf{3 4}$ & $\mathbf{3 5}$ & $\mathbf{3 6}$ & $\mathbf{3 7}$ & $\mathbf{3 8}$ & $\mathbf{3 9}$ \\
\hline Africanomys kettarati & 0 & 0 & 0 & 0 & $?$ & $?$ & $?$ & $?$ & $?$ & $?$ & $?$ & $?$ & $?$ & $?$ & 1 & 1 & 1 & 0 & 0 & 0 & 1 & 0 & $?$ & 1 & 0 & $?$ & $?$ & $?$ & $?$ & $?$ & $?$ & $?$ & 1 & 2 & 0 & 1 & 0 & 0 & 1 \\
\hline Irhoudia robinsoni & 1 & 0 & 1 & $?$ & $?$ & $?$ & $?$ & $?$ & $?$ & $?$ & $?$ & $?$ & $?$ & $?$ & 1 & 1 & 0 & 1 & 0 & 1 & 1 & $0 \& 1$ & 2 & 0 & 0 & 0 & 1 & 0 & $?$ & $?$ & $?$ & $?$ & 2 & 2 & 1 & 2 & 0 & $0 \& 1$ & $?$ \\
\hline Irhoudia bohlini & 1 & 0 & 2 & 0 & 1 & 2 & 0 & 0 & 0 & 1 & $?$ & $?$ & $?$ & $?$ & 1 & 1 & 0 & 1 & 0 & 1 & 2 & $0 \& 1$ & 2 & 0 & 0 & 0 & 1 & 1 & $?$ & $?$ & $?$ & $?$ & 2 & 2 & 1 & 2 & 0 & $0 \& 1$ & 1 \\
\hline Pellegrinia panormensis & 2 & 1 & 2 & - & - & - & - & - & - & - & - & - & - & - & 2 & 1 & - & 2 & 0 & 0 & 2 & 1 & 2 & 0 & 2 & 0 & - & - & - & - & - & - & 2 & 2 & 0 & 2 & 0 & 1 & 1 \\
\hline Pectinator spekei & 1 & 0 & 0 & 0 & 1 & 2 & 0 & 0 & 0 & 1 & 2 & 0 & 1 & 0 & 1 & 1 & 1 & 0 & 0 & 0 & 0 & 0 & 2 & 1 & 0 & 2 & 2 & 2 & 2 & 0 & 0 & 2 & 2 & 2 & 0 & 2 & 1 & 0 & 1 \\
\hline Ctenodactylus gundi & 1 & 1 & 2 & 1 & 1 & 2 & 0 & 1 & 0 & 2 & 2 & 0 & - & 0 & 2 & 1 & 0 & 1 & 0 & 1 & 1 & 0 & 2 & 0 & 0 & 2 & 2 & 2 & 2 & 0 & 0 & 2 & 1 & 2 & 0 & 2 & 2 & 0 & 0 \\
\hline Ctenodactylus vali & 1 & 1 & 2 & 1 & 1 & 2 & 0 & 1 & 0 & 2 & 2 & 0 & - & 0 & 2 & 1 & 0 & 1 & 0 & 1 & 1 & 0 & 2 & 0 & 0 & 2 & 2 & 2 & 2 & 0 & 0 & 2 & 1 & 2 & 0 & 2 & 2 & 0 & 0 \\
\hline Massoutiera mzabi & 1 & 1 & 2 & 1 & 1 & 2 & 0 & 1 & 0 & 2 & 2 & 0 & - & 0 & 2 & 1 & 0 & 1 & 0 & 1 & 0 & 1 & 2 & 0 & 0 & 1 & 2 & 2 & 2 & 0 & 0 & 2 & 1 & 2 & 1 & 2 & 0 & 1 & 0 \\
\hline Felovia vae & 1 & 1 & 2 & 1 & 1 & 2 & 0 & 1 & 0 & 2 & 2 & 0 & - & 0 & 1 & 1 & 0 & 1 & 0 & 1 & 0 & 1 & 2 & 0 & 0 & 0 & 2 & 2 & 2 & 0 & 0 & 2 & 1 & 2 & 1 & 2 & 0 & 1 & 1 \\
\hline
\end{tabular}


